\title{
Discerning natural and anthropogenic organic matter inputs to salt marsh sediments of Ria Formosa lagoon (South Portugal)
}

\author{
Mukesh Kumar $^{1,2} \cdot$ Tomasz Boski $^{1} \cdot$ Francisco J. González-Vila ${ }^{3} \cdot$ José Ma de la Rosa $^{3} \cdot$ José A. González-Pérez $^{3}$ (D)
}

Received: 20 December 2019 / Accepted: 11 May 2020/Published online: 18 May 2020

(C) Springer-Verlag GmbH Germany, part of Springer Nature 2020

\begin{abstract}
Sedimentary organic matter $(\mathrm{OM})$ origin and molecular composition provide useful information to understand carbon cycling in coastal wetlands. Core sediments from threors' Contributionse transects along Ria Formosa lagoon intertidal zone were analysed using analytical pyrolysis (Py-GC/MS) to determine composition, distribution and origin of sedimentary OM. The distribution of alkyl compounds (alkanes, alkanoic acids and alkan-2-ones), polycyclic aromatic hydrocarbons (PAHs), lignin-derived methoxyphenols, linear alkylbenzenes (LABs), steranes and hopanes indicated OM inputs to the intertidal environment from natural—autochthonous and allochthonous—as well as anthropogenic. Several $n$-alkane geochemical indices used to assess the distribution of main OM sources (terrestrial and marine) in the sediments indicate that algal and aquatic macrophyte derived OM inputs dominated over terrigenous plant sources. The lignin-derived methoxyphenol assemblage, dominated by vinylguaiacol and vinylsyringol derivatives in all sediments, points to large OM contribution from higher plants. The spatial distributions of PAHs (polyaromatic hydrocarbons) showed that most pollution sources were mixed sources including both pyrogenic and petrogenic. Low carbon preference indexes (CPI $>1$ ) for $n$-alkanes, the presence of UCM (unresolved complex mixture) and the distribution of hopanes $\left(\mathrm{C}_{29}-\mathrm{C}_{36}\right)$ and steranes $\left(\mathrm{C}_{27}-\mathrm{C}_{29}\right)$ suggested localized petroleum-derived hydrocarbon inputs to the core sediments. Series of LABs were found in most sediment samples also pointing to domestic sewage anthropogenic contributions to the sediment OM.
\end{abstract}

Keywords Coastal lagoon · Aliphatic hydrocarbon $\cdot$ Lignin $\cdot$ Polycyclic aromatic hydrocarbons $\cdot$ Hopanes $\cdot$ Steranes $\cdot$ Linear alkylbenzenes

\section{Introduction}

Salt marshes are vegetated coastal habitats, which occur along coastlines at mid to high latitudes and recognized as one of the most productive ecosystems on Earth (Mitsch and Gosselink

Responsible editor: Vedula VSS Sarma

Electronic supplementary material The online version of this article (https://doi.org/10.1007/s11356-020-09235-9) contains supplementary material, which is available to authorized users.

José A. González-Pérez

jag@irnase.csic.es

1 CIMA, Universidade do Algarve, 8005-139 Faro, Portugal

2 Universidad de Cádiz, Campus de Puerto Real, 11519 Puerto Real, Cadiz, Spain

3 IRNAS - CSIC. MOSS Group, Avda. Reina Mercedes 10, 41012 Seville, Spain
1993; Aller and Cochran 2019). Salt marshes located in the Portuguese South Atlantic coast occupy the intertidal range within lagoonal and estuarine systems and are susceptible to a growing anthropogenic impact. Salt marshes covering the sheltered segments of coastal zones function as organic carbon sinks and archives of environmental change during the periods of sediment accumulation. Salt marshes play a key role in fixing atmospheric carbon, retaining nutrients and pollutants acting also as a coastal protection buffer and nursery ground for many species (Chmura et al. 2003; Duarte et al. 2013). Sedimentary deposits in salt marshes elsewhere are a proxy surrogate to sea-level changes (Delgado et al. 2012; Kumar et al. 2018), carbon accumulation rates (Ouyang and Lee 2014) and salinity dynamics (Byrne et al. 2001) being also used as historical records of pollution (Leorri et al. 2014). Sedimentary OM in salt marsh coastal wetlands have received special attention because it retains characteristics of its autochthonous, extant and anthropogenic sources. Thus, the assessment of different source contribution to the sediment pool of 
salt marshes is essential for the understanding of their role in carbon cycling as well as ecological importance. Organic carbon fate in intertidal salt marsh sediment is ambiguous because of the complicating effects of sediment resuspension, early diagenetic alterations and bioturbation.

Thus, the discrimination between anthropogenic and biogenic inputs from petrogenic, pyrogenic and domestic waste sources must rely on geochemical or molecular biomarkers for complete fingerprinting of OM in salt marshes, as a part of the multi-proxy approach. For that purpose, here we use aliphatic hydrocarbon (n-alkanes, $n$-alkanoic acids, $n$-alkan-2-ones), PAHs, hopanes and sterane biomarkers to study the sedimentary origin of organic matter deposited in salt marshes of Ria Formosa lagoon.

The principal aim of this work was to study the molecular distribution of Py-GC/MS biomarkers in intertidal core sediments retrieved from three transects covering saltmarsh vegetation and tidal mudflats. The technique is fast and reproducible, extensively used for the structural characterization of soil and sediments by a heat-mediated degradation of OM macromolecules into smaller fragments that are amenable and can be identified by GC/MS (Jiménez-Morillo et al. 2016). It is expected that the findings from this study will ultimately be of use for better management of the ecological resources of Ria Formosa coastal lagoon as well as for the maintenance of the environmental health.

\section{Materials and methods}

\section{Study area descriptions}

The Ria Formosa coastal lagoon is located on the Algarve coast (South Portugal) in the bay of Cadiz. The lagoon is protected by a series of barrier islands along the coast from the Atlantic Ocean: two peninsulas (Ancão and Cacela) and five barrier-island systems (from west to east: Barreta or Ilha Deserta, Culatra, Armona, Tavira and Cabanas). The lagoon has cuspate shape geomorphology. The lagoon is extended over ca. $55 \mathrm{~km}$ length along the coast, $6 \mathrm{~km}$ at its widest point and covers an area ca. $80 \mathrm{~km}^{2}$. The average depth relative to mean sea level is $2 \mathrm{~m}$ (Andrade et al. 2004). The Ria Formosa is a mesotidal coastal lagoon with semi-diurnal tides with maximum amplitude recorded in the macrotidal range $(3.5 \mathrm{~m})$, though average tidal range varies between 2.8 for spring and 1.3 neap tides (Pacheco et al. 2008). Annual average temperature in the area is around $17{ }^{\circ} \mathrm{C}$ and receives annual precipitation between 600 and $800 \mathrm{~mm}$ (Duarte et al. 2008). Climatic condition of the region is Mediterranean with hot/dry summers and warm/wet winters, classified as Csb or Csa in the Koppen's classification system. There is no large river draining into the Ria Formosa lagoon, and all tributaries draining into lagoon are ephemeral. The fresh water inflow to the lagoon occurs mainly in winter season during the sporadic rainfalls and through a system of small draining rivulets. During the summer months, the rate of evaporation exceeds that of the total influx of freshwater to the lagoon, resulting into a hyper saline condition in the upper stretches of the channels (Mudge et al. 2008).

The Ria Formosa lagoon is consisting of an extensive intertidal area with a branched system of creeks and channels. A recent study, focused in the evolution of the Ria Formosa barrier island system during the Holocene, suggests that the stabilization of the lagoon occurred during mid-Holocene, with the phenomenon of slowdown sea level rise rate (Sousa et al. 2019). The lagoon salt marshes and tidal flats depositional environments are characterized with silt content more than $50 \%$, clay content varies between 10 and $20 \%$, and coarse sand content less than 5\% (Sousa et al. 2019).

Floristically, the Ria Formosa system lagoon is dominated by macrophytes. Salt marsh vegetation is mainly composed of two dominant species (Spartina maritima and Sarcocornia fruticosa) that grow in parallel bands to the shoreline. Spartina maritima (small cordgrass) is a pioneer species mainly located in the lower marshes flooded with the high tides and exposed during the low ones. On the other hand, in the less frequently flooded mid-high marsh, the dominant species is Sarcocornia fruticosa. Seagrass populations of Zostera noltii are found colonizing intertidal mudflats, whereas the subtidal areas are dominated by the seagrasses Cymodocea nodosa, Zostera marina and Zostera noltii (Cunha et al. 2009). Ria Formosa is surrounded by terrestrial plants Pinus pinea also known as umbrella or stone pine, which is a typical pine tree species from the Mediterranean climatic region. Phragmites australis occupies a band at the upper border of salt marsh ecotone.

The lagoon provides breeding ground and nursery for numerous birds and other animal and plant species, several listed as threatened or endangered (Ribeiro et al. 2008). The Ria Formosa has been placed under the Ramsar Convention wetlands category (Convention on Wetlands of International Importance) list and also is listed as a European Union Natura 2000 site.

The intertidal salt marsh habitats in the lagoon have been heavily degraded by human activities i.e. untreated discharge of municipal and industrial effluents, solar pond construction, airport operations and aquaculture (Bebianno 1995). Furthermore, the lagoon marshes are strictly confined due to recent economic development around the lagoon that significantly restricts the adjustments of marshes toward landward migration. Furthermore, socioeconomic transformation during the twentyfirst century, such as tourism, change in agricultural practices, shell farming and the expansion of salt mining, has seriously modified the catchment areas and the lagoon ecosystem.

\section{Sediment sampling and processing}

A previous detailed field survey was done in Ria Formosa lagoon to select the best intertidal salt marsh sites to establish 


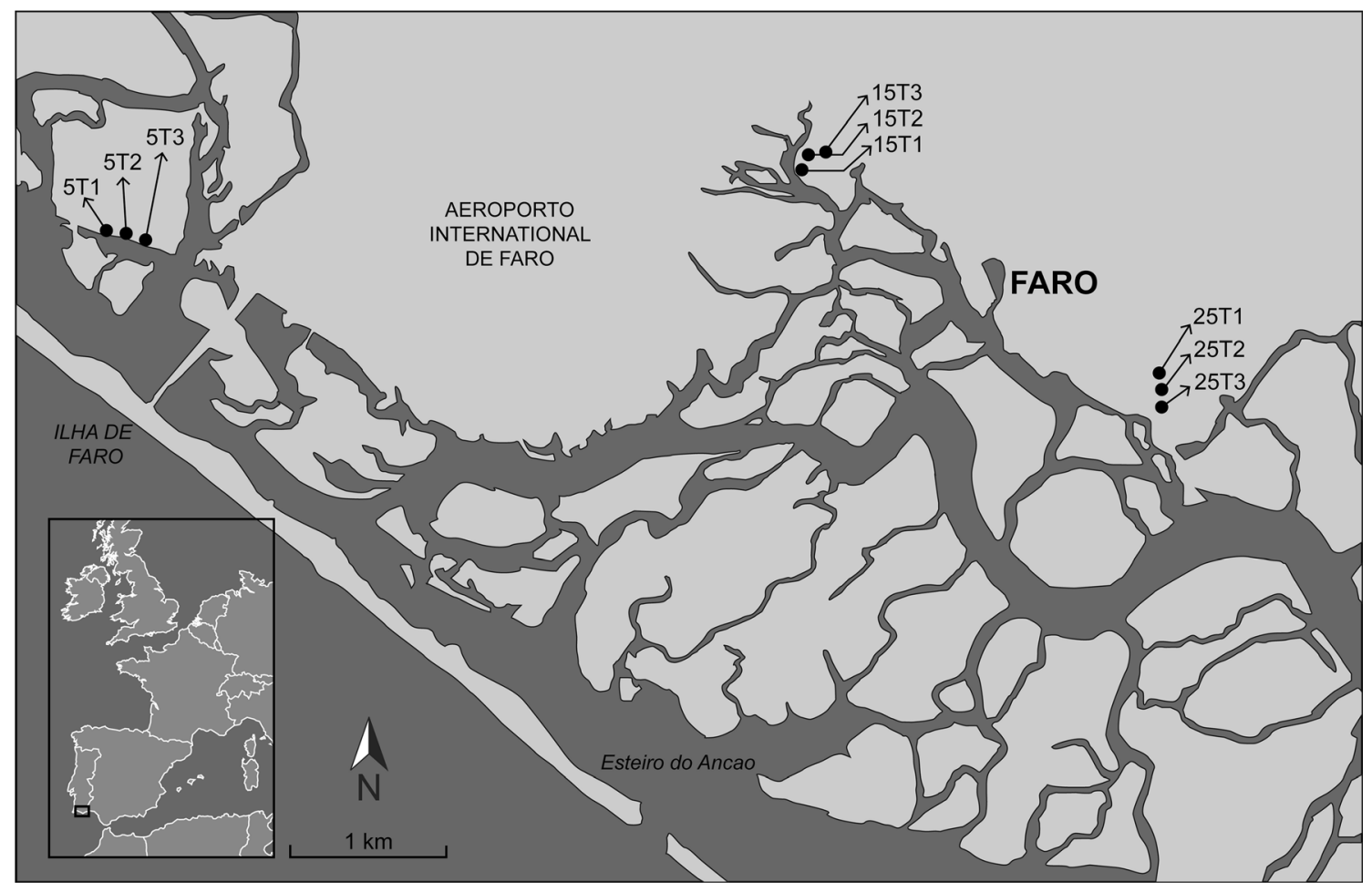

Fig. 1 Study area map with the locations of transects (5T, 15T, 25T) and cores taken in the Ria Formosa lagoon (South Portugal)

the transects. In August 2015, three transects were selected, and nine cores (1-m deep) were retrieved with a manual Eijkelkamp auger. The sediment core locations in all three transects are depicted in Fig. 1. Transect 5T is located away from Faro City and represents a pristine area of Ria Formosa, $15 \mathrm{~T}$ is situated close to Faro city in an area under the possible influence of domestic effluents and transect $25 \mathrm{~T}$ is located close to the commercial harbour under the possible influence of industrial effluents. Each transect consists of three cores (T1, T2 and T3) taken in the intertidal region of the lagoon; core $\mathrm{T} 1$ was retrieved from the woody glasswort (Sarcocornia fruticosa) site, which occurs at mid to high tidal range, core T2 is from the cord grass (Spartina maritima) site and core T3 was located in the mudflats. All the cores were sectioned at regular intervals of $10 \mathrm{~cm}$, individually wrapped in aluminium foil and immediately send to the laboratory for freeze-drying. Samples were then disaggregated and pestle in a mortar and further homogenized and fine ground in a ball mill and dry stored before analyses. For this study, three distinct sections of the sediment core, that is surface $(0-10 \mathrm{~cm})$, medium part (30$40 \mathrm{~cm}$ ) and deep $(90-100 \mathrm{~cm})$, were analysed.

\section{Sediment EC and pH}

The $\mathrm{pH}$ and electrical conductivity (EC) were analysed in 1:2.5 sediment to Milli-Q water ratio $(\mathrm{g} / \mathrm{ml})$ extracts; the suspension was left to stand for $2 \mathrm{~h}$ prior to the $\mathrm{pH}$ determination using a pH-meter (Crison Mod. GLP 22) previously calibrated with buffer solutions ( $\mathrm{pH} 4.00,7.00$ and 10.00). The EC was measured in the saturated extract of the sediments using an EC-Meter (Crison Mod. BASIC $30+$ ).

\section{Analytical pyrolysis and the calculation of biogeochemical proxies}

The Py-GC-MS analyses were done in a double-shot pyrolyser (Frontier Laboratories model 2020i, Fukushima, Japan), coupled to a GC/MS system (Agilent model 6890, Santa Clara, CA). The samples for analysis (ca. $10 \mathrm{mg}$ ) were weighed in a steel capsule and introduced for $1 \mathrm{~min}$ in the pyrolyser micro-furnace preheated at $500{ }^{\circ} \mathrm{C}$. The pyrolysate was then directly transferred into the GC-MS for analysis. A low polar-fused silica (5\%-phenyl-methyl polysiloxane) column (Agilent J\&W HP-5msUI, of $30 \mathrm{~m} \times 250 \mathrm{~mm} \times 0.25 \mathrm{~mm}$ film thickness) was used for compound separation with $\mathrm{He}$ as carrier gas at a flow of $1 \mathrm{~mL} / \mathrm{min}$. The GC oven was held for $1 \mathrm{~min}$ at $50{ }^{\circ} \mathrm{C}$ and then the temperature was increased up to $100{ }^{\circ} \mathrm{C}$ at $30^{\circ} \mathrm{C} / \mathrm{min}$, from 100 to $300{ }^{\circ} \mathrm{C}$ at $10{ }^{\circ} \mathrm{C} / \mathrm{min}$ and stabilized at $300^{\circ} \mathrm{C}$ for the last $10 \mathrm{~min}$. The eluted compounds were detected in a mass spectrometer (Agilent model 5973 $\mathrm{MSD}$ ) and $70 \mathrm{eV}$ electron was used for ionization. The system configuration can detect organic compounds well below the trace level $(<0.1 \mathrm{ppm})$. To ensure a clean system, to evaluate contamination and that no carryover occurred from successive samples, method blanks using dichloromethane and hexane were included every five samples. 
Finally, the compounds were identified by comparison with stored mass spectra libraries (NIST and Wiley) and published data and by selecting single diagnostic ions for homologous series. Several biogeochemical proxies were inferred from the chromatographic areas of the alkane series released during the sediments pyrolysis.

Short to long hydrocarbon chains $\mathrm{S} / \mathrm{L}$ (short/long) ratio and average weighted carbon chain lengths (ACL) for long $n$-alkanes $\left(\mathrm{C}_{24-33}\right)$ range were calculated as follows:

$$
\begin{aligned}
& \mathrm{S} / \mathrm{L}=\sum(\mathrm{Cn})_{10-23} / \sum(\mathrm{Cn})_{24-33} \\
& \mathrm{ACL}=\sum(\mathrm{n} \times \mathrm{Cn})_{24-33} / \sum(\mathrm{Cn})_{24-33}
\end{aligned}
$$

$n$ : number of $\mathrm{C}$ atoms; $[\mathrm{Cn}]$ alkane relative abundance

The carbon preference index CPI ${ }_{(24-33)}$ indicates odd to even $\mathrm{C}$ chain numbers relative abundance in long chain hydrocarbons. The CPI index is informative about the original sedimentary OM source. When CPI value $>1 \mathrm{im}-$ plies that the odd $\mathrm{C}$ numbered chains prevail and that the main input to the sediment is from plants, while CPI values $<1$ points to $\mathrm{OM}$ degradation in the sediments or to inputs from bacteria or algae biomass (Bray and Evans 1961). Here, CPI index was calculated considering the hydrocarbon molecules with 24 to 33 carbons using a modified formula of Cranwell (1984) as described in Kumar et al. (2020) as follows:

$\mathrm{CPI}_{(24-33)}=0.5 \times\left[\sum(\mathrm{Cn} \text { odd })_{25-33} / \sum(\mathrm{Cn} \text { even })_{24-32+} \sum(\mathrm{Cn} \text { odd })_{25-33} / \sum(\mathrm{Cn} \text { even })_{26-32}\right]$

[Cn odd]: odd-numbered; [Cn even]: even-numbered C hydrocarbon chains

The terrigenous/aquatic ratio TAR (Bourbonniere and Meyers 1996) for $n$-alkanes distinguish plants and algal inputs to sediments. This proxy was calculated with the equation:

$\mathrm{TAR}=\left(\mathrm{C}_{27}+\mathrm{C}_{29}+\mathrm{C}_{31}\right) /\left(\mathrm{C}_{15}+\mathrm{C}_{17}+\mathrm{C}_{19}\right)$

Paq proxy (Ficken et al. 2000) informs of inputs to the lacustrine sediments from aquatic macrophytes and terrestrial and emergent plants and was calculated as follows:

Paq $=\left(\mathrm{C}_{23}+\mathrm{C}_{25}\right) /\left(\mathrm{C}_{23}+\mathrm{C}_{25}+\mathrm{C}_{29}+\mathrm{C}_{31}\right)$

Analytical pyrolysis is especially useful in detecting the presence and characteristics of lignin monomers (methoxyphenols) in sediments and soils (Tinoco et al. 2002; Miralles et al. 2015). The composition of lignin and of its monomers varies with the degree of alteration in the sediment (Hedges and Mann 1979). Therefore, in addition, and to study the specific lignin contribution to the sediments, the presence of 12 methoxyphenols in the pyrolysates was analysed by selecting specific diagnostic ions; six of the guaiacyl and six of the syringyl type.

\section{Results and discussion}

\section{Sediments EC and pH}

The sediments $\mathrm{EC}$ and $\mathrm{pH}$ values in core profiles are in Table 1. Core sediments $\mathrm{pH}$ values ranged between 4.54 and 9.00. In general, lower $\mathrm{pH}$ values were observed at vegetated sites core sediments than in bare mudflat sites, and most of the sediment samples showed an increasing $\mathrm{pH}$ trend with depth (Table 1). Typically, organic-rich salt marsh sediments are redox stratified and usually, an intensive sulphate reduction occurs due to rapid mineralization of OM (Madureira et al. 1997). The $\mathrm{pH}$ and redox conditions of belowground sedimentary layers of salt marsh sediments are affected by vegetation. This is due to fact that belowground roots system and macrofaunal burrows in sediments can translocate oxygen into sedimentary layers, which favours pyrite oxidation leading to an increase in sediment acidity (Hines et al. 1989; Madureira et al. 1997). In contrast, $\mathrm{H}^{+}$is consumed in the processes of anoxic OM decomposition (e.g. nitrate, sulphate, iron or manganese reductions), which increases the sediment $\mathrm{pH}$. In nonvegetated mudflat sites core sediments profile, the conditions in all layers remained anoxic except in the sediment-water interface layers, and thus, changes in sediment $\mathrm{pH}$ values are not recorded with depth.

The core sediments EC values ranged between 4.79 and $38.20 \mu \mathrm{S} / \mathrm{cm}$ (Table 1). The highest EC value was recorded at Sarcocornia fruticosa site surface sediment (25T1 0 $10 \mathrm{~cm}$ ) and the lowest was at mudflat site surface sediment (5T3 0-10 cm). Sarcocornia fruticosa site core sediments showed higher EC values than those in Spartina maritima and mudflat sites, while sediment EC values displayed a decreasing trend with depth in core sediment profiles. Generally, in salt marsh ecosystems, soil/sediment moisture decrease with increasing proximity to the upland salt marsh vegetation and evaporation process governs subsurface salinity gradients within the intertidal zone. Here, the EC values recorded for the core sediments were found constant in the deeper portion of the core sediments, which may be related to inundation and exposure during the tidal cycles, which govern pore water geochemistry of the salt marsh sediments.

\section{Sources of sedimentary $n$-alkanes}

The $n$-alkane series were identified in selected-ion-monitoring (SIM) chromatogram using $\mathrm{m} / \mathrm{z}, 57$ as the diagnostic ion. An example of the histograms prepared from the pyrograms of sediments and illustrating the distribution of $n$-alkane $/ n$-alk-1ene doublets in transect 25T is in Fig. 2a, and the results for all transects are in Fig. S1. The distribution of $n$-alkane series chain length along the salt marsh transects ranged between $\mathrm{C}_{10}$ and $\mathrm{C}_{33}$ reflecting diverse OM sources in the intertidal sediments of the lagoon. 
Table $1 \mathrm{pH}, \mathrm{EC}$ (electrical conductivity), $n$-alkanes chain length and $n$-alkanes proxies

\begin{tabular}{|c|c|c|c|c|c|c|c|c|c|c|c|c|}
\hline & Core site & $\begin{array}{l}\text { Sediment } \\
\text { depth }\end{array}$ & $\mathrm{pH}$ & $\begin{array}{l}\mathrm{CE} \\
(\mu \mathrm{S} / \mathrm{cm})\end{array}$ & Range & $\mathrm{C} \max$ & $\begin{array}{l}\mathrm{CPI}(24- \\
33)\end{array}$ & $\mathrm{S} / \mathrm{L}$ & $\begin{array}{l}\text { ACL(24- } \\
33)\end{array}$ & $\begin{array}{l}\text { ACL }(10- \\
33)\end{array}$ & Paq & TAR \\
\hline \multirow{9}{*}{$\begin{array}{l}5 \mathrm{~T} \\
\text { tran- } \\
\text { sect }\end{array}$} & \multirow{3}{*}{$\begin{array}{l}\text { T1 (Sarcocornia } \\
\quad \text { fruticosa) }\end{array}$} & $5 \mathrm{~T} 10-10 \mathrm{~cm}$ & 6.68 & 16.98 & C10-C31 & $\mathrm{C} 13, \mathrm{C} 24$ & 0.84 & 4.58 & 26.20 & 17.45 & 0.80 & 0.22 \\
\hline & & $\begin{array}{l}5 \mathrm{~T} 1 \\
\quad 30-40 \mathrm{~cm}\end{array}$ & 5.30 & 13.76 & $\mathrm{C} 10-\mathrm{C} 31$ & $\mathrm{C} 13, \mathrm{C} 21, \mathrm{C} 25$ & 1.44 & 3.55 & 26.52 & 18.39 & 0.73 & 0.39 \\
\hline & & $\begin{array}{l}5 \mathrm{~T} 1 \\
\quad 90-100 \mathrm{~cm}\end{array}$ & 6.08 & 5.64 & C10-C33 & $\mathrm{C} 12, \mathrm{C} 17, \mathrm{C} 31$ & 1.64 & 5.01 & 26.91 & 17.52 & 0.70 & 0.28 \\
\hline & \multirow{3}{*}{$\begin{array}{c}\text { T2 (Spartina } \\
\text { maritima })\end{array}$} & $5 \mathrm{~T} 20-10 \mathrm{~cm}$ & 6.43 & 5.35 & C10-C33 & $\mathrm{C} 15, \mathrm{C} 25$ & 1.76 & 2.73 & 27.05 & 19.09 & 0.61 & 0.58 \\
\hline & & $\begin{array}{l}5 \mathrm{~T} 2 \\
\quad 30-40 \mathrm{~cm}\end{array}$ & 6.84 & 6.63 & C10-C33 & $\mathrm{C} 13, \mathrm{C} 19, \mathrm{C} 25$ & 1.65 & 4.79 & 26.56 & 17.68 & 0.72 & 0.30 \\
\hline & & $\begin{array}{l}5 \mathrm{~T} 2 \\
\quad 90-100 \mathrm{~cm}\end{array}$ & 4.54 & 6.20 & $\mathrm{C} 10-\mathrm{C} 30$ & $\mathrm{C} 11, \mathrm{C} 20, \mathrm{C} 29$ & 1.39 & 8.37 & 26.19 & 17.39 & 1.84 & 0.18 \\
\hline & \multirow[t]{3}{*}{ T3 (Mudflat) } & $5 \mathrm{~T} 30-10 \mathrm{~cm}$ & 8.06 & 7.36 & C10-C31 & $\mathrm{C} 13, \mathrm{C} 23$ & 1.57 & 3.39 & 26.58 & 18.64 & 0.69 & 0.45 \\
\hline & & $\begin{array}{l}5 \mathrm{~T} 3 \\
\quad 30-40 \mathrm{~cm}\end{array}$ & 7.91 & 5.42 & C10-C33 & $\mathrm{C} 13, \mathrm{C} 19, \mathrm{C} 27$ & 1.64 & 4.18 & 27.08 & 17.95 & 0.61 & 0.42 \\
\hline & & $\begin{array}{l}5 \mathrm{~T} 3 \\
\quad 90-100 \mathrm{~cm}\end{array}$ & 7.66 & 4.79 & $\mathrm{C} 10-\mathrm{C} 25$ & $\mathrm{C} 11$ & ND & 67.3 & 24.33 & 14.38 & 1.00 & 0.00 \\
\hline \multirow{9}{*}{$\begin{array}{c}15 \mathrm{~T} \\
\text { tran- } \\
\text { sect }\end{array}$} & \multirow[t]{3}{*}{$\begin{array}{l}\text { T1 (Sarcocornia } \\
\quad \text { fruticosa) }\end{array}$} & $\begin{array}{l}15 \mathrm{~T} 1 \\
0-10 \mathrm{~cm}\end{array}$ & 6.77 & 19.76 & $\mathrm{C} 10-\mathrm{C} 33$ & $\mathrm{C} 13, \mathrm{C} 19, \mathrm{C} 25$ & 1.38 & 3.77 & 26.28 & 18.53 & 0.81 & 0.31 \\
\hline & & $\begin{array}{l}15 \mathrm{~T} 1 \\
30-40 \mathrm{~cm}\end{array}$ & 7.32 & 11.47 & ND & ND & ND & ND & ND & ND & ND & ND \\
\hline & & $\begin{array}{l}15 \mathrm{~T} 1 \\
90-100 \mathrm{~cm}\end{array}$ & 7.53 & 11.97 & ND & ND & ND & ND & ND & ND & ND & ND \\
\hline & \multirow[t]{3}{*}{$\begin{array}{r}\mathrm{T} 2 \text { (Spartina } \\
\text { maritima) }\end{array}$} & $\begin{array}{l}15 \mathrm{~T} 2 \\
0-10 \mathrm{~cm}\end{array}$ & 7.30 & 15.21 & C10-C33 & $\mathrm{C} 12, \mathrm{C} 21$ & 1.57 & 4.28 & 26.35 & 18.29 & 0.82 & 0.26 \\
\hline & & $\begin{array}{l}15 \mathrm{~T} 2 \\
30-40 \mathrm{~cm}\end{array}$ & 8.01 & 11.11 & C10-C31 & $\mathrm{C} 12, \mathrm{C} 21, \mathrm{C} 27$ & 2.05 & 6.38 & 26.72 & 17.05 & 0.69 & 0.29 \\
\hline & & $\begin{array}{l}15 \mathrm{~T} 2 \\
90-100 \mathrm{~cm}\end{array}$ & 8.91 & 7.56 & C10-C31 & $\mathrm{C} 12, \mathrm{C} 19$ & 1.67 & 8.96 & 25.98 & 16.68 & 0.84 & 0.14 \\
\hline & \multirow[t]{3}{*}{ T3 (Mudflat) } & $\begin{array}{l}15 \mathrm{~T} 3 \\
0-10 \mathrm{~cm}\end{array}$ & 6.67 & 17.77 & C10-C33 & $\mathrm{C} 15, \mathrm{C} 21$ & 1.56 & 3.84 & 26.54 & 18.27 & 0.76 & 0.35 \\
\hline & & $\begin{array}{l}15 \mathrm{~T} 3 \\
30-40 \mathrm{~cm}\end{array}$ & 8.65 & 11.74 & C10-C33 & $\mathrm{C} 13, \mathrm{C} 23$ & 1.62 & 4.67 & 26.42 & 18.01 & 0.80 & 0.29 \\
\hline & & $\begin{array}{l}15 \mathrm{~T} 3 \\
90-100 \mathrm{~cm}\end{array}$ & 8.28 & 13.78 & C10-C33 & $\mathrm{C} 13, \mathrm{C} 19$ & 1.76 & 5.45 & 26.33 & 17.71 & 0.81 & 0.23 \\
\hline \multirow{9}{*}{$\begin{array}{l}25 \mathrm{~T} \\
\text { tran- } \\
\text { sect }\end{array}$} & \multirow[t]{3}{*}{$\begin{array}{l}\text { T1 (Sarcocornia } \\
\quad \text { fruticosa) }\end{array}$} & $\begin{array}{l}25 \mathrm{~T} 1 \\
0-10 \mathrm{~cm}\end{array}$ & 6.65 & 38.20 & $\mathrm{C} 10-\mathrm{C} 33$ & $\mathrm{C} 15, \mathrm{C} 21$ & 1.39 & 2.61 & 26.97 & 19.60 & 0.72 & 0.48 \\
\hline & & $\begin{array}{l}25 \mathrm{~T} 1 \\
30-40 \mathrm{~cm}\end{array}$ & 7.29 & 21.00 & C10-C33 & $\mathrm{C} 14, \mathrm{C} 21, \mathrm{C} 29$ & 1.28 & 2.40 & 27.73 & 19.74 & 0.58 & 0.65 \\
\hline & & $\begin{array}{l}25 \mathrm{~T} 1 \\
90-100 \mathrm{~cm}\end{array}$ & 7.79 & 8.63 & C10-C33 & $\mathrm{C} 13, \mathrm{C} 19, \mathrm{C} 31$ & 1.41 & 4.98 & 26.96 & 17.44 & 0.71 & 0.26 \\
\hline & \multirow[t]{3}{*}{$\begin{array}{r}\mathrm{T} 2 \text { (Spartina } \\
\text { maritima) }\end{array}$} & $\begin{array}{l}25 \mathrm{~T} 2 \\
0-10 \mathrm{~cm}\end{array}$ & 6.70 & 17.07 & C10-C33 & $\mathrm{C} 12, \mathrm{C} 21, \mathrm{C} 31$ & 1.47 & 2.91 & 26.89 & 19.30 & 0.76 & 0.40 \\
\hline & & $\begin{array}{l}25 \mathrm{~T} 2 \\
30-40 \mathrm{~cm}\end{array}$ & 6.70 & 11.74 & C10-C33 & $\mathrm{C} 12, \mathrm{C} 25, \mathrm{C} 29$ & 1.31 & 2.49 & 27.41 & 19.53 & 0.64 & 0.58 \\
\hline & & $\begin{array}{l}25 \mathrm{~T} 2 \\
90-100 \mathrm{~cm}\end{array}$ & 9.00 & 7.63 & C10-C33 & $\mathrm{C} 12, \mathrm{C} 29$ & 1.32 & 1.84 & 28.91 & 20.29 & 0.30 & 1.06 \\
\hline & \multirow[t]{3}{*}{ T3 Core (Mudflat) } & $\begin{array}{l}25 \mathrm{~T} 3 \\
0-10 \mathrm{~cm}\end{array}$ & 7.75 & 14.31 & C10-C33 & $\mathrm{C} 12, \mathrm{C} 21$ & 1.31 & 3.00 & 27.48 & 19.04 & 0.67 & 0.46 \\
\hline & & $\begin{array}{l}25 \mathrm{~T} 3 \\
30-40 \mathrm{~cm}\end{array}$ & 7.85 & 14.45 & C10-C33 & $\mathrm{C} 12, \mathrm{C} 21$ & 1.50 & 2.98 & 26.94 & 19.07 & 0.73 & 0.41 \\
\hline & & $\begin{array}{l}25 \mathrm{~T} 3 \\
90-100 \mathrm{~cm}\end{array}$ & 8.68 & 10.06 & C10-C33 & $\mathrm{C} 13, \mathrm{C} 29$ & 1.40 & 2.51 & 28.45 & 19.43 & 0.42 & 0.74 \\
\hline
\end{tabular}

$C P I(24-33)$ carbon preference index, $A C L$ average chain length, $T A R$ terrigenous/aquatic ratio, $P a q$ aquatic proxy, $(S / L)$ short/long chain $n$-alkanes ratio, $N D$ not detected

The short-chain $n$-alkane series $\left(\mathrm{C}_{10}-\mathrm{C}_{20}\right)$ found in all core sediments with no $\mathrm{C}$ number predominance points to multiple OM sources such as bacterial reworking, marine phytoplankton and also to matured petrogenic hydrocarbons (Cranwell et al. 1987; Kennicutt II et al. 1987; Kumar et al. 2018). 

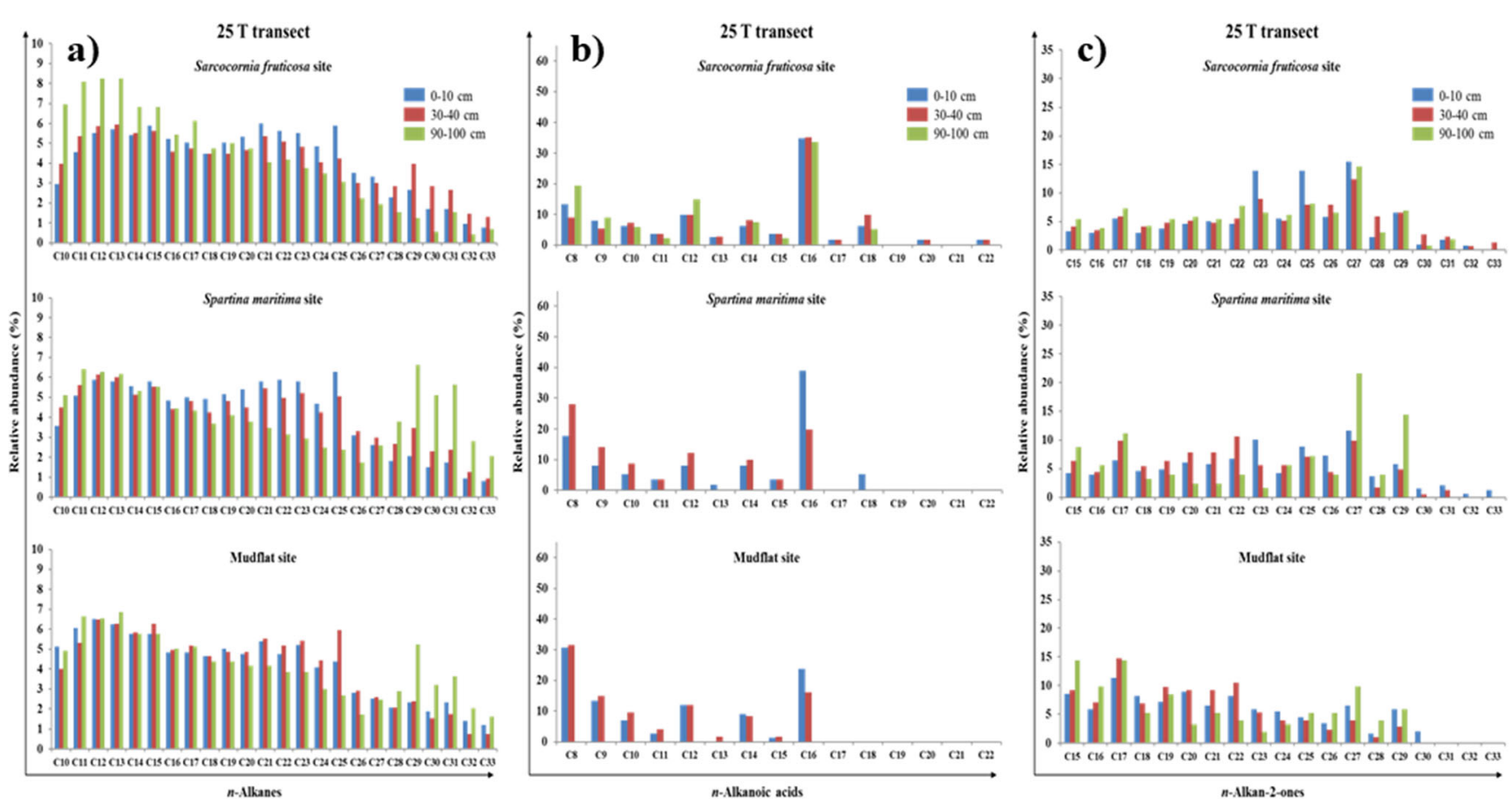

Fig. 2 Histograms of the a $n$-alkane $(m / z, 57), \mathbf{b} n$-alkanoic acid $(\mathrm{m} / z, 73)$ and $\mathbf{c} n$-alkan-2-one $(\mathrm{m} / \mathrm{z}, 59)$ series obtained by direct pyrolysis (Py-GC/MS) of the sediments from the three sites and depths for transect $25 \mathrm{~T}$

Also, the large relative abundance of mid-chain $\left(\mathrm{C}_{21}-\mathrm{C}_{25}\right)$ $n$-alkane series found in all core sediments is probably reflecting contributions from submerged/floating macrophytes. The high Paq index values $>0.4$ recorded for the majority of samples (Table 1) also provide evidence for a large input from aquatic macrophytes (Ficken et al. 2000). However, a single sediment sample $(25 \mathrm{~T} 290-100 \mathrm{~cm})$ with $\mathrm{P} a q$ value close to 0.4 may point to contributions from macrophytes. The seagrass species (Zostera noltii, Cymodocea nodosa and Zostera marina) that densely occupy intertidal and subtidal areas of the Ria Formosa lagoon (Cunha and Santos 2009) might be other source of mid-chain $n$-alkanes (Chevalier et al. 2015). Core sediments particularly from $25 \mathrm{~T}$ transect exhibit a conspicuous abundance at $\mathrm{C}_{25}$ homologue (Fig. 2). Such large abundance of $\mathrm{C}_{25} n$-alkane in the salt marsh sedimentary OM pool has been previously attributed to leaf waxes of Sarcocornia fruticosa (Grossi and Raphel 2003) and Salicornia europaea (Tanner et al. 2010).

Long-chain $n$-alkanes $\left(\mathrm{C}_{27}-\mathrm{C}_{33}\right)$ are less abundant than short and mid-chain $n$-alkanes in all core sediments (Fig. 2; Fig. S1). The $n$-alkanes, particularly these with high odd/even $\mathrm{C}$ predominance, are attributed to the contribution not only of higher plant waxes but also from emergent aquatic macrophytes (Eglinton and Hamilton 1967; Ficken et al. 2000).

The molecular distribution of $n$-alkanes in plant waxes are of chemotaxonomic relevance and can be related to distinct plant species (Schwark et al. 2002). The $n$-alkane compositions in the long-chain range from Sarcocornia fruticosa sites show Cmax at $\mathrm{C}_{27}$ homologue. In contrast, Spartina site and mudflat site core sediments exhibit $\mathrm{Cmax}$ at $\mathrm{C}_{29}$ and $\mathrm{C}_{31}$ homologues. The observed distribution of long-chain $n$-alkanes agrees with previous findings reporting the dominance of $n$-alkanes peaking at the $\mathrm{C}_{27}$ homologue in the Mediterranean salt marsh species Sarcocornia fruticosa (Grossi and Raphel 2003) and at the $\mathrm{C}_{29}$ homologue in the species Spartina alterniflora and Spartina patens (Tanner et al. 2007). Nonetheless, an alternative source of $\mathrm{C}_{29}$ homologue in the sediments may be the pine vegetation (Gonzalez-Vila et al. 2003) widespread in catchment areas of Ria Formosa lagoon. Other studies indicate that seagrasses can also contribute to the organic pool with $\mathrm{C}_{29}$ chain length alkanes (Jaffé et al. 2001). This interpretation is reinforced by the occurrence of abundant seagrasses (Cymodocea nodosa, Zostera marina, and Zostera noltii) in the subtidal area of Ria Formosa lagoon (Cunha et al. 2009).

Despite the considerable dominance of the salt marsh vegetation (mainly Salicornia fruticosa and Spartina maritima) in the intertidal zone, the low relative abundance of long-chain $n$ alkanes $\left(\mathrm{C}_{27}-\mathrm{C}_{33}\right)$ observed indicates a limited terrigenous contribution to the $\mathrm{OM}$ in the sediments. Two reasons may explain this $n$-alkane pattern: (1) Low rainfall in the Algarve region may be limiting the terrestrial OM supply through runoff in the lagoon system and (2) the tidal transport from salt marsh derived OM (outwelling) to the ocean. Odum et al. (1979) recognized that coastal salt marshes are nutrient exporters and "outwell" organic carbon through the tidal exchange. This outwelling can be relevant in the Ria Formosa where four inlets from the adjacent Atlantic Ocean are known 
to account for $50 \%$ the tidal flushing within 1 day (Mudge et al. 1998).

Downcore enrichment of long-chain $n$-alkanes observed in the depth intervals $30-40 \mathrm{~cm}$ and $90-100 \mathrm{~cm}$ in $25 \mathrm{~T}$ transect is most probably linked with resuspension-deposition cycles in which terrestrial OM accumulates in the sediments. More labile planktonic algal and bacterial OM are believed to be affected by microbial degradation during sedimentary diagenesis. This leads to a stronger terrestrial signature preserved in deeper samples. Long-chain $n$-alkanes, derived from epicuticular wax of vascular plants leaves, are comparatively more resistant to degradation under the anoxic conditions in the sediments (Hedges and Keil 1995). Many factors can affect OM preservation in continental margin sediments, such as the accumulation rate of the sediments and the exposure to $\mathrm{O}_{2}$, as well as possible sorption to the surface of minerals, but the precise mechanisms responsible for preservation remain unclear (Hedges and Keil 1995). Mayer (1994) found a positive correlation between the amount of sedimentary OM and the clay contents. Clays have very large specific surface areas, which, in turn, may effectively protect the organic molecules through chemical binding or physical sealing (Boski et al. 1998).

The carbon preference index of $n$-alkanes (CPI) has been used as a proxy for hydrocarbon degradation in sediments (Bray and Evans 1961; Allan and Douglas 1977). The terrestrial plants that contain $n$-alkanes with $\mathrm{C}_{25}-\mathrm{C}_{31}$ carbon numbers generally show strong odd over even (CPI). Moreover, CPI is used to indicate the degree of diagenesis of geolipids and can be also used to estimate the proportion of preserved original chains (Meyers and Ishiwatari 1993). Accordingly, we applied this index to our analytical values (Table 1) for all three transects sediment core samples. The index for longchain molecules CPI (24-33) ranged from 0.84 to 2.05 (average $1.50 \pm 0.53$ ) (Table 1). Values of CPI ${ }_{(24-33)}>1$ indicate terrestrial OM input (Bray and Evans 1961) and CPI (24-33) values close to 1 or $<1$ indicate input from a mixture of algal, bacterial biomass, recycled OM and/or petroleum inputs to the core sediments (Cranwell et al. 1987; Kennicutt II et al. 1987).

Based on $n$-alkanes distribution in the sediments, the average chain length (ACL) proxy was also calculated. Although the trend among the tree studied transect is $5 \mathrm{~T}<15 \mathrm{~T}<25 \mathrm{~T}$, pointing to a crescent terrigenous influence, no systematic variation is observed (Table 1). The ACL for the $5 \mathrm{~T}$ transect ranged from 14.38 to $19.09(17.61 \pm 1.35)$ for the $15 \mathrm{~T}$ from 17.05 to $18.56(17.79 \pm 0.69)$ and for the $25 \mathrm{~T}$ transect from 17.44 to 20.29 (19.27 \pm 0.78$)$. The low ACL values recorded for $5 \mathrm{~T}$ and $15 \mathrm{~T}$ transect core sediments can be attributable to their relative abundance in short-chain peaks in the range $C_{12}$ to $\mathrm{C}_{15}$. Apart from the major contributors to the Ria Formosa marsh sediments as described before (bacterial reworking or marine phytoplankton), the input of hydrocarbons from petrogenic (without oil seepage) can also result in sedimentary alkane assemblages with low ACL values (Jeng 2006; Kumar et al. 2018). Climate parameters (temperature and precipitation) can have also an effect on $n$-alkanes ACL values (Schefuß et al. 2003; Tipple and Pagani 2013).

Vegetation may also influence sedimentary $n$-alkanes ACL values. Tidal salt marshes are an assemblage of different photosynthetic pathways plants (C3, C4 or CAM). Sarcocornia fruticosa (CAM plant) and Spartina spp (C4 plants) are two dominant tidal marshes present in our study area with the potential to leave a discernible molecular imprint. Higher plant $n$-alkane ACL values are also known to be related to the vegetation type and latitude (Rommerskirchen et al. 2006; Tipple and Pagani 2013). In particular, C4-type plants (mainly fast grown grasses) wax signature is characterized by larger contents of long-chain $\mathrm{C}_{31}$ and $\mathrm{C}_{33} n$-alkanes. Therefore, we would expect that salt marsh sediments under C4 plants i.e. Spartina spp. could have higher $n$-alkanes ACL values than those under C3 plants i.e. Salicornia spp. However, in this study, we were unable to differentiate OM derived from either $\mathrm{C} 3$ plants or $\mathrm{C} 4$ plants based on $n$-alkanes ACL values, but just a wider $n$-alkane range in surface sediments $(0-10 \mathrm{~cm})$ under Sparina maritima $(\mathrm{C} 4)$ than under Salicornia (C3) vegetated sites for the three transects of for Ria Formosa salt marsh core sediments. This is probably caused by OM mixing from salt marsh vegetation due to the tidal action.

Both CPI and ACL proxies cannot distinguish alone the inputs from submerged or floating macrophytes to sediments derived OM. Further, long-chain $n$-alkanes are produced not only by terrestrial plants but also by some macrophytes (Ficken et al. 2000; McKirdy et al. 2010) and has been successfully applied to coastal lagoon associated with larger OM inputs from submerged/floating macrophytes (McKirdy et al. 2010). Thus, we used the additional parameter Paq $n$-alkane to delineate the nature and origin of OM deposited in intertidal core sediments of Ria Formosa tidal salt marshes. The Paq ranged from 0.61 to 1.84 for $5 \mathrm{~T}$ transect core samples and from 0.69 to 0.84 (Table 1) for $15 \mathrm{~T}$ transect core samples, suggesting a major contribution from submerged macrophytes. For the more inland transect $25 \mathrm{~T}$, this value ranged between 0.30 and 0.76 (Table 1), suggesting a mixed OM input from both terrestrial and submerged macrophytes to core sediments.

To distinguish possible shifts in the OM relative contributions from land and aquatic flora to the sedimentary deposits, a Terrigenous-to-Aquatic Ratio (TAR) was calculated for all sampled core sediments (Table.1). The TAR values from $5 \mathrm{~T}$ transect range from 0 to 0.58 and from 0.14 to 0.35 for the $15 \mathrm{~T}$ transect. While for $25 \mathrm{~T}$ transect, TAR ranges between 0.26 and 1.06. TAR value $>1$ indicate a larger contribution from terrestrial plants to sedimentary OM. Conversely, a TAR value $<1$ indicates autochthonous inputs in an eutrophic system (Bourbonniere and Meyers 1996). The TAR values from all three transects are overwhelmingly lower than 1 , indicating a 
predominant autochthonous source of $n$-alkanes in the cored sediments. High TAR values can also occur in a marine environment due to a preferential preservation of more resilient terrestrial hydrocarbons over planktonic ones. This fact may produce an overestimation of terrigenous sources to the sediments (Meyers 1997).

\section{n-Alkanoic acids (fatty acids)}

A series of $n$-alkanoic acids was found in the sediments that ranged between $\mathrm{C}_{8: 0}$ and $\mathrm{C}_{22: 0}$ (Fig. 2b; Fig. S2). The distribution pattern is characterized by $\mathrm{Cmax}$ at $\mathrm{C}$ 16:0 homologue, a unimodal pattern and a strong even-over-odd hydrocarbon chain length predominance. The distribution pattern exhibits a decrease in the abundance of $n$-alkanoic acids depth. There are drawbacks when using pyrolysis for $n$ - alkanoic acids detection, mainly derived from the apolar chromatographic columns used and to the occurrence of secondary reactions that may happen at pyrolysis temperatures (Dignac et al. 2006). Short-chain $<\mathrm{C}_{20: 0} n$-alkanoic acids are chief components of algal and bacterial biomass (Cranwell et al. 1987). However, $\mathrm{C}_{16: 0}$ (palmitic acid) homologue is ubiquitous in the biosphere and present in bacteria, algae and plants (Meyers 1997). Previous studies have shown that a large abundance of $\mathrm{C}_{16: 0}$ homologue in salt marsh sediments is possibly attributed to salt marsh detritus (Meziane et al. 1997; Canuel et al. 1997).

A previous study of lipid biomarkers in Ria Formosa surface sediments suggest that the distribution of $n$-alkanoic acid in over $90 \%$ of the sampled sites was centred on $\mathrm{C}_{16: 0}$ homologue and most likely attributed to seagrasses and the seasonal blue-green algae blooming in the lagoon (Mudge et al. 1998). It is also known that Ria Formosa lagoon is highly affected by direct input from domestic sewage (Mudge et al. 1998; Mudge and Duce 2005) that can also bring $n$-alkanoic acids such as $\mathrm{C}_{16: 0}, \mathrm{C}_{18: 0}$ and $\mathrm{C}_{18: 1}$ to coastal areas that modify the natural abundance in the sediments (Quemeneur and Marty 1992). However, a decrease in the relative abundances with downcore depth in the sediment package $(0-10>30-40>$ $90-100 \mathrm{~cm}$ ) points to the effect of sedimentary diagenesis of $n$-alkanoic acids (Meyers and Eadie 1993). Moreover, the increasing occurrence of $n$-alkanoic acids with the distance to the seashore $(5 \mathrm{~T}<15 \mathrm{~T}<25 \mathrm{~T})$ points to a terrigenous contribution from higher plants or domestic sludge origin (cooking oils) (Fig. 2b; Fig. S2).

\section{Acyclic methyl ketones ( $n$-alkan-2-ones)}

The sediment pyrolysates of the Ria Formosa lagoon contained well-resolved series of $n$-alkane-2-ones $(\mathrm{m} / z \quad 59$ ion chromatograms) in the range $\mathrm{C}_{15}$ to $\mathrm{C}_{33}$ and an odd over even chain-length predominance (Fig. 2c; Fig. S3). These alkanones have been detected in many sedimentary environments vegetated with seagrasses, salt marshes and mangrove forest, with molecular distribution typically showing a Cmax at the $\mathrm{C}_{25}, \mathrm{C}_{27}$ or $\mathrm{C}_{29}$ homologues (e.g. Hernandez et al. 2001; Jaffé et al. 2001; Gonzalez-Vila et al. 2003; De la Rosa et al. 2012; Kumar et al. 2019). Long-chain $n$-alkane-2-ones ( $\left.>C_{25}\right)$ with Cmax at $\mathrm{C}_{27}, \mathrm{C}_{29}$ and $\mathrm{C}_{31}$ homologues have been also found in terrestrial plants and specifically in the salt marsh Juncus spp. shows a series peaking at the $\mathrm{C}_{27}$ homologue (Ortiz et al. 2011). Juncus vegetation is frequent in the upper tidal zone of Ria Formosa lagoon, and this species may be contributing to the $n$-alkane-2-one signature with Cmax at $\mathrm{C}_{27}$ as seen in the Sarcocornia fruticosa and Spartina maritima sediments of transects $15 \mathrm{~T}$ and $25 \mathrm{~T}$. The $n$-alkane2-one series with $\mathrm{Cmax}$ at $\mathrm{C}_{25}$ homologues are attributed to seagrass species (Hernandez et al. 2001) that are abundant in the Ria Formosa intertidal and sub-tidal zones. Moreover, short-chain $n$-alkane-2-one $\left(<\mathrm{C}_{25}\right)$ has been found in phytoplankton and in bacterial derived biomass (Rielley et al. 1991; Qu et al. 1999). The $n$-alkane-2-one molecular distributions observed here are in good agreement with those previously found by de la Rosa et al. (2012) in salt marsh sediments from the estuary of Minho River (NW Spain).

The $n$-alkane-2-one series from $\mathrm{C}_{15}$ to $\mathrm{C}_{33}$ and with carbon odd predominance over even has been reported also to occur in aerosols from Eastern Mediterranean regions (Gogou et al. 1996). Therefore, an atmospheric fallout could not be discarded as an alternative source of $n$-alkane-2-one source to the sediments. The presence and distribution of $n$-alkane2-one in aquatic sediments is thought to be the result of postdepositional modifications of precursors (Hernandez et al. 2001) and generally formed by an $\alpha$-oxidation of $n$-alkanes caused by microbes (Cranwell et al. 1987) or by $n$-alkanoic acids $\beta$-oxidation and decarboxylation (Volkman et al. 1983). Due to the fact that in this study we were unable to detect a correspondence between the distribution of most abundant $n$ alkane-2-ones and of $n$-alkanoic acids precludes the degradation of fatty acids as $n$-alkane-2-ones source. However, the similarities between the molecular distributions pattern of alkanes and $n$-alkane-2-ones found suggest that $n$-alkane-2-ones in the sediments most probably originated from $\alpha$-oxidation of $n$-alkanes caused by the microbial activity (Cranwell et al. 1987).

\section{UCM}

The unresolved complex mixture (UCM) denotes a hump under the chromatogram baseline that appears in some soil and sediments (Gough and Rowland 1990). This chromatographic feature, composed of hundreds of unresolved peaks that are not separated during the chromatography, is often used to indicate an anthropogenic contamination by petroleum in coastal areas (Volkman et al. 1992; He et al. 2018; Dashtbozorg et al. 2019). The total ion chromatogram (TIC) obtained from the $25 \mathrm{~T}$ transect core sediments, situated near 

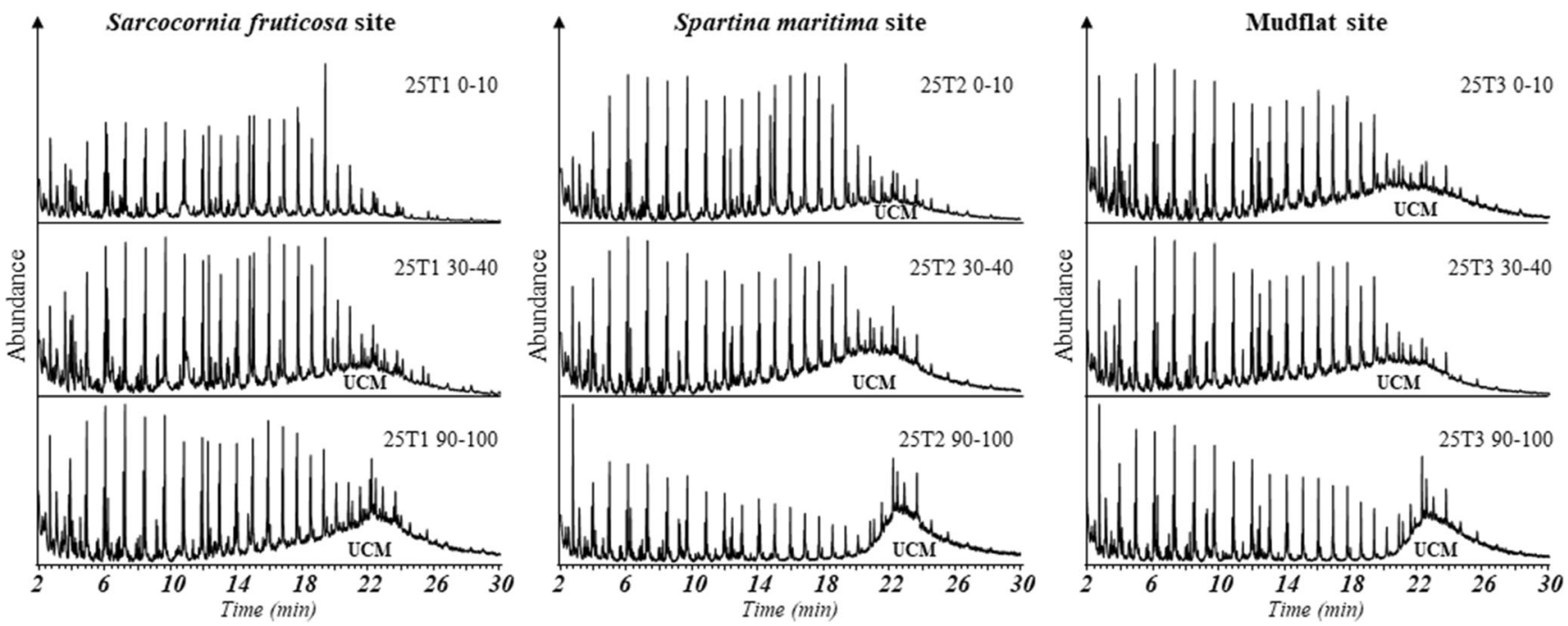

Fig. 3 Example of the mass chromatograms $(m / z, 57)$ including the distribution of $n$-alkanes and the unresolved complex mixture (UCM) in the sediments from transect $25 \mathrm{~T}$

the city and harbour of Faro, are depicted in Fig. 3. A conspicuous UCM is apparent in all the sediment samples. This point to the occurrence of contamination by petroleum spills. Whereas the UCM in the $\mathrm{C}_{10}-\mathrm{C}_{20} n$-alkane range has been attributed to a bacteria-mediated decay of algal material (Venkatesan and Kaplan 1982), in our samples, the UCM found in the range of $n$-alkanes $\mathrm{C}_{20}-\mathrm{C}_{33}$ evidences the presence of petroleum-derived residues. This is also confirmed by the occurrence of hopane and sterane biomarkers. The UCMs are more resistant to biodegradation than $n$-alkanes and thus frequently accumulate in the sedimentary and aquatic environment (Aboul-Kassim and Simoneit 1995).

\section{Phenolic compounds}

\section{Alkylphenol series}

Phenolic compounds and alkylated homologues were also identified in the pyrograms by selecting the diagnostic ions (Fig. 4). The alkylphenol series is dominated by Phenol ( $\mathrm{P} ; \mathrm{m} / \mathrm{z}, 94)$, C1Phenols (MP; $m / z$ 108), C2-Phenols (DMP; $m / z$ 122) and C3Phenols (TMP; $m / z$ 136). The relative abundances of phenolic compounds diminish with the length of the alkyl side chain $(\mathrm{P}>\mathrm{MP}>$ DMP $>$ TMP). These short-chain alkylphenols co-occur with methoxy-substituted alkylphenols that are characteristic in the pyrolysis of lignin (Sáiz-Jiménez and De Leeuw 1984), thus ascribed as terrigenous input. A similar alkylphenol distribution to that found in this work has been identified by analytical pyrolysis elsewhere i.e. in OM collected in sediment traps at different depths from the NW Mediterranean sea and surface sediments from the Arctic Ocean (Peulvé et al. 1996a, b), suspended materials from the Rhone delta (Sicre et al. 1994) and in sediments from the North-West African upwelling system (Zegouagh et al. 1999). Though, these short-chain alkylphenols can be also yielded in the pyrolysis of brown macroalgae phlorotannins (Van Heemst et al. 1996).

\section{Methoxyphenols derivatives}

Little attention has been given to lignin occurrence and to the composition of their structural units in the salt marsh sediments, even when this plant-derived compound is a major part of the socalled "blue carbon" with a huge environmental relevance (Mcleod et al. 2011; Cragg et al. 2020). Here, a selection of 12 methoxyphenols based on the guaiacyl and alkyl- and keto- derivatives (G, MG, EG, VG, PG and AG) and on the syringyl alkyl- and keto- derivatives (S, MS, ES, VG, PG, AG) was identified as described by Tinoco et al. (2002). An example of lignin presence in the sediment is in Fig. 4, and a semiquantification assessment of the different lignin sub-units is compiled in Table 2. Both guaiacyl (G) and syringyl (S) units were found confirming that sedimentary OM pool comprised lignin from gymnosperm and also angiosperm plants (Hedges and Mann 1979; Tinoco et al. 2002). Among the guaiacyl units, G, MG and VG were more abundant than EG, PG and AG (Table 2). While, among syringyl derivatives, S, VS and PS were more abundant than MS, ES and AS unit. In general, a decreasing with depth was observed for the relative abundance of methoxyphenol derivatives in the transect core sediments investigated in our study. Also, an abundance of methoxyphenols is observed in the more in-land transect 25T, evidencing a larger terrigenous contribution to sedimentary $\mathrm{OM}$. While $\mathrm{G}$ units were found in most samples, $\mathrm{S}$ units were only detected in the Sarcocornia site (T1) surface sediment of transect $15 \mathrm{~T}$ and in the vegetated cores ( $\mathrm{T} 1$ and $\mathrm{T} 2$ ) of transect $25 \mathrm{~T}$. We were unable to detect lignin $\mathrm{S}$ units in mudflat sites sediments.

The semi-quantitative assessment of lignin composition revealed that core sediment pyrolysates are characterized 


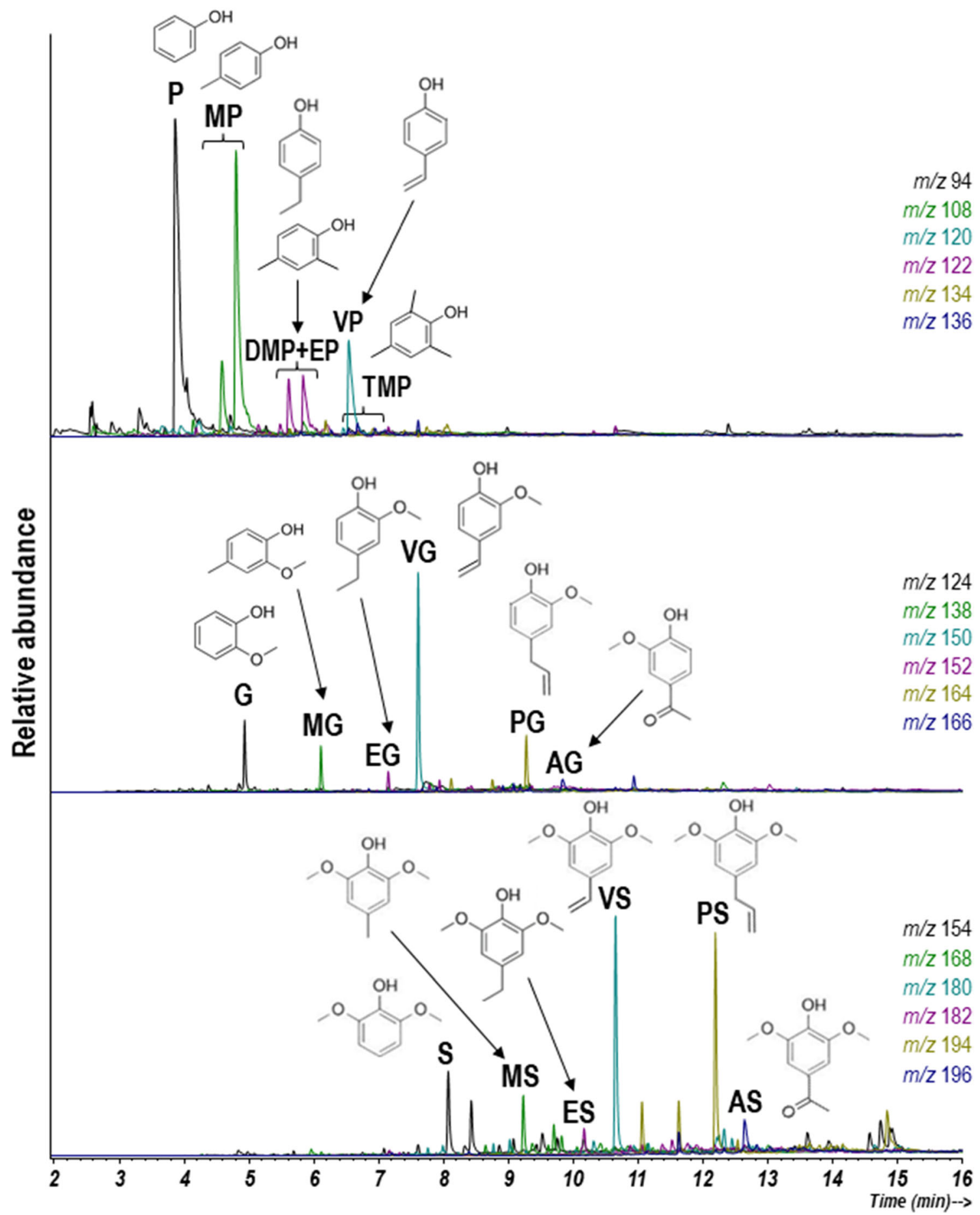

Fig. 4 Example chromatogram with selected extracted diagnostic ions for phenolic compounds. Pyrolysis of core sediment samples from the salt marsh sediments. The chromatogram is for sample 25T1 $30-40 \mathrm{~cm}$. P phenol, MP methyl phenol, DMP dimethyl phenol, TMP trimethyl phenol, G: guaiacol, MG methylguaiacol, EG ethylguaiacol, VG vinylguaiacol, PG propenylguaiacol, PS propenylsyringol, AG acetoguaiacone, S syringol, MS methylsyringol, ES ethylsyringol, VS vinylsyringol, PS propenylsyringol, AS: acetosyringone

ferulic acids during the pyrolysis of $\mathrm{OM}$, which are abundant in polyphenols in herbaceous tissue (Hedges and Mann 1979; Ralph and Hatfield 1991). Sporopollenin by the predominance of 4-vinylguaiacol (VG) and 4vinylsyringol (VS) (Table 2). Usually, these lignin units are produced by a decarboxylation of $p$-coumaric and 
Table 2 Lignin pyrolysis products semiquantitative assessment in the transect core sediments profiles. Diagnostic ions traces for selected 12 lignin derived methoxyphenols as described by Tinoco et al. (2002)

\begin{tabular}{|c|c|c|c|c|c|c|c|c|c|c|c|c|c|c|}
\hline & Core site & $\begin{array}{l}m / z \\
\text { Sediment depth }\end{array}$ & $\begin{array}{l}124 \\
G\end{array}$ & $\begin{array}{l}154 \\
S\end{array}$ & $\begin{array}{l}138 \\
\mathrm{MG}\end{array}$ & $\begin{array}{l}168 \\
\text { MS }\end{array}$ & $\begin{array}{l}152 \\
E G\end{array}$ & $\begin{array}{l}182 \\
\text { ES }\end{array}$ & $\begin{array}{l}150 \\
\text { VG }\end{array}$ & $\begin{array}{l}180 \\
\text { VS }\end{array}$ & $\begin{array}{l}164 \\
P G\end{array}$ & $\begin{array}{l}194 \\
\text { PS }\end{array}$ & $\begin{array}{l}166 \\
\mathrm{AG}\end{array}$ & $\begin{array}{l}196 \\
\text { AS }\end{array}$ \\
\hline \multirow[t]{9}{*}{$5 \mathrm{~T}$ transect } & \multirow[t]{3}{*}{ T1 (Sarcocornia fruticosa) } & $5 \mathrm{~T} 10-10 \mathrm{~cm}$ & + & - & $+/-$ & - & $+/-$ & - & +++ & - & - & - & - & - \\
\hline & & $5 \mathrm{~T} 130-40 \mathrm{~cm}$ & +++ & - & ++ & - & + & - & ++ & - & - & - & - & - \\
\hline & & BT1 90-100 cm & - & - & - & - & - & - & - & - & - & - & - & - \\
\hline & \multirow[t]{3}{*}{ T2 (Spartina maritima) } & $5 \mathrm{~T} 20-10 \mathrm{~cm}$ & - & - & - & - & - & - & - & - & - & - & - & - \\
\hline & & $5 \mathrm{~T} 230-40 \mathrm{~cm}$ & +++ & - & ++ & - & ++ & - & +++ & - & + & - & - & - \\
\hline & & $5 \mathrm{~T} 290-100 \mathrm{~cm}$ & + & - & $+/-$ & - & $+/-$ & - & + & - & - & - & - & - \\
\hline & \multirow[t]{3}{*}{ T3 (Mudflat) } & $5 \mathrm{~T} 30-10 \mathrm{~cm}$ & - & - & - & - & - & - & - & - & - & - & - & - \\
\hline & & $5 \mathrm{~T} 330-40 \mathrm{~cm}$ & +++ & - & ++ & - & ++ & - & +++ & - & + & - & - & - \\
\hline & & 5 T3 $90-100 \mathrm{~cm}$ & ++ & - & + & - & $+/-$ & - & + & - & - & - & - & - \\
\hline \multirow[t]{9}{*}{$15 \mathrm{~T}$ transect } & \multirow[t]{3}{*}{ T1 (Sarcocornia fruticosa) } & $15 \mathrm{~T} 10-10 \mathrm{~cm}$ & +++ & +++ & + & - & + & - & +++ & - & $+/-$ & + & $+/-$ & $+/-$ \\
\hline & & $15 \mathrm{~T} 130-40 \mathrm{~cm}$ & - & - & - & - & - & - & - & - & - & - & - & - \\
\hline & & $15 T 190-100 \mathrm{~cm}$ & - & - & - & - & - & - & - & - & - & - & - & - \\
\hline & \multirow[t]{3}{*}{ T2 (Spartina maritima) } & $15 \mathrm{~T} 20-10 \mathrm{~cm}$ & +++ & - & ++ & - & + & - & +++ & - & + & - & - & - \\
\hline & & $15 \mathrm{~T} 230-40 \mathrm{~cm}$ & - & - & - & - & - & - & - & - & - & - & - & - \\
\hline & & $15 \mathrm{~T} 290-100 \mathrm{~cm}$ & - & - & - & - & - & - & - & - & - & - & - & - \\
\hline & \multirow[t]{3}{*}{ T3 (Mudflat) } & $15 \mathrm{~T} 30-10 \mathrm{~cm}$ & +++ & - & ++ & - & + & - & ++ & - & + & - & - & - \\
\hline & & $15 \mathrm{~T} 330-40 \mathrm{~cm}$ & ++ & - & - & - & $+/-$ & - & - & - & - & - & - & - \\
\hline & & $15 \mathrm{~T} 390-100 \mathrm{~cm}$ & ++ & - & - & - & - & - & - & - & - & - & - & - \\
\hline \multirow[t]{9}{*}{$25 \mathrm{~T}$ transect } & \multirow[t]{3}{*}{ T1 (Sarcocornia fruticosa) } & $25 \mathrm{~T} 10-10 \mathrm{~cm}$ & +++ & +++ & ++ & - & + & - & +++ & +++ & + & +++ & $+/-$ & ++ \\
\hline & & $25 \mathrm{~T} 130-40 \mathrm{~cm}$ & +++ & +++ & ++ & - & + & - & +++ & +++ & ++ & +++ & + & $+/-$ \\
\hline & & $25 \mathrm{~T} 190-100 \mathrm{~cm}$ & +++ & - & ++ & - & ++ & - & +++ & ++ & ++ & ++ & - & - \\
\hline & \multirow[t]{3}{*}{ T2 (Spartina maritima) } & $25 \mathrm{~T} 20-10 \mathrm{~cm}$ & +++ & + & ++ & - & ++ & - & +++ & ++ & ++ & +++ & + & $+/-$ \\
\hline & & $25 \mathrm{~T} 230-40 \mathrm{~cm}$ & +++ & - & ++ & - & + & - & +++ & - & + & - & $+/-$ & - \\
\hline & & $25 \mathrm{~T} 290-100 \mathrm{~cm}$ & $+/-$ & - & $+/-$ & - & - & - & $+/-$ & - & - & - & - & - \\
\hline & \multirow[t]{3}{*}{ T3 Core (Mudflat) } & $25 \mathrm{~T} 30-10 \mathrm{~cm}$ & +++ & - & ++ & - & $+/-$ & - & +++ & - & + & - & $+/-$ & - \\
\hline & & $25 \mathrm{~T} 330-40 \mathrm{~cm}$ & +++ & - & ++ & - & ++ & - & +++ & - & ++ & - & - & - \\
\hline & & $25 \mathrm{~T} 390-100 \mathrm{~cm}$ & + & - & - & - & $+/-$ & - & $+/-$ & - & - & - & - & - \\
\hline
\end{tabular}

$G$ guaiacol, $S$ syringol, $M G$ methylguaiacol, $M S$ methylsyringol, $E G$ ethylguaiacol, $E S$ ethylsyringol, $V G$ vinylguaiacol, $V S$ vinylsyringol, $P G$ propenylguaiacol, $P S$ propenylsyringol, $A G$ acetoguaiacone, $A S$ acetosyringone

Semiquantitative assessment: (+++) most abundant; (++) abundant; (+) present; (+/-) trace; (-) not detected

(covering around spores) of aquatic plants can be also an alternative precursor, particularly for 4-vinylguaiacol (Nierop et al. 2011). Using analytical pyrolysis techniques, Kaal et al. (2016) showed that the phenolic compounds 4vinylphenol, VG and VS are abundant in plants and sediments under Mediterranean seagrasses (Posidonia oceanica) mats. The distribution of $\mathrm{G}$ type lignin and conspicuous peaks for catechol and methylcatechols point to the occurrence of degraded lignin with demethylation of the methoxy groups (Filley et al. 2002). However, Galletti and Reeves (1992) demonstrated that catechols are also associated with the presence of tannins. Thus, tannin could not be discarded as a possible source of catechols $(1,2$ benzenediols) to the sediments.

\section{PAHs}

Polycyclic aromatic hydrocarbons (PAHs) are hydrophobic in nature and readily adsorb onto the particulate matter that can enter the water column through urban runoff and ultimately deposited in coastal and marine sediments. Sedimentary PAHs bear carcinogenic and mutagenic activities that may affect and threaten aquatic organisms (Wakeham et al. 1980). The accumulation of PAHs in the sedimentary environment is controlled by sediment characteristics that include granulometry and texture (Zhang et al. 2004) and the organic carbon content (Kim et al. 1999). Intertidal salt marsh sediments are characterized by having abundant detritus, large organic carbon content and an anoxic environment that facilitate PAHs accumulation. 
Fig. 5
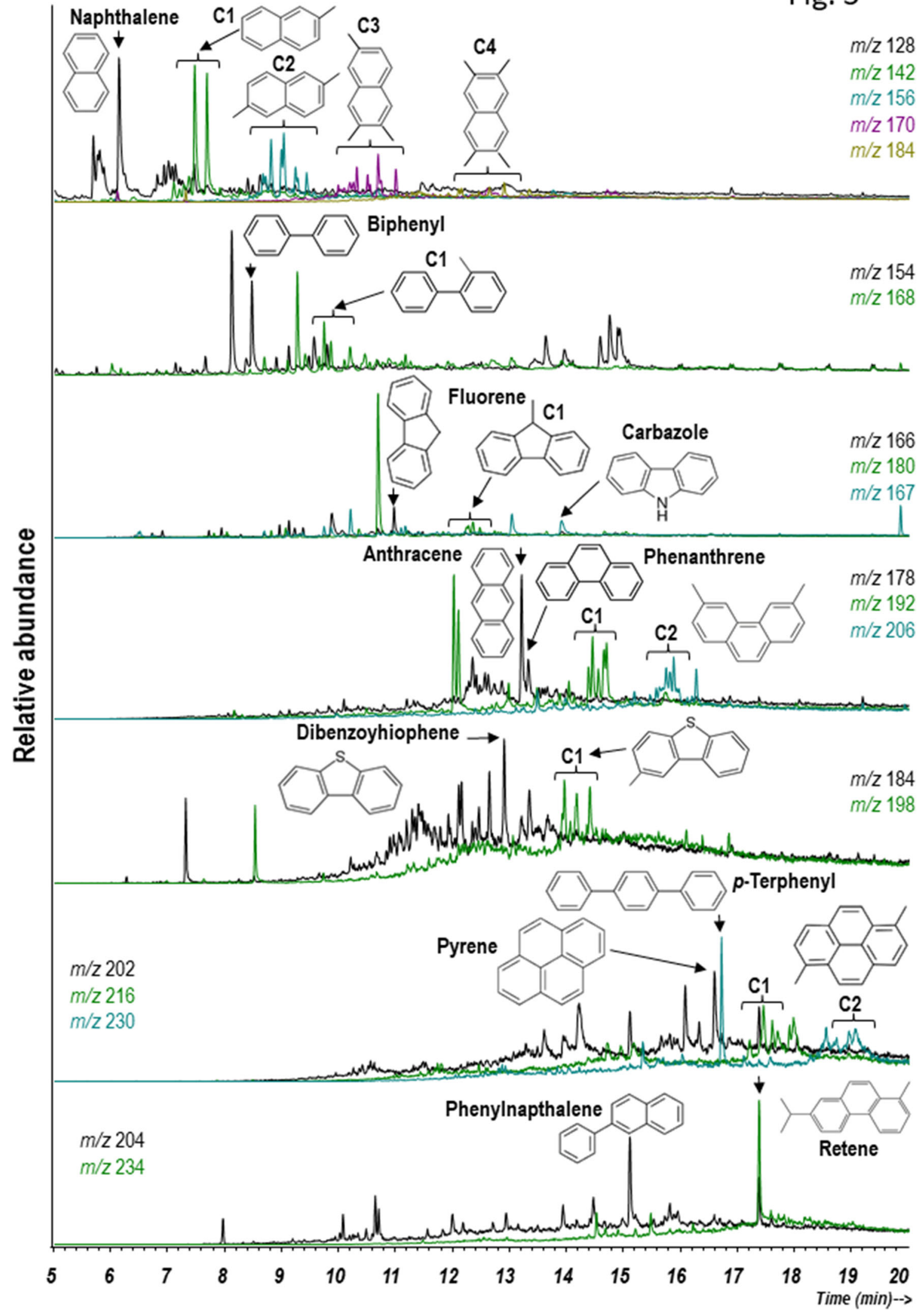
4 Fig. 5 Distribution of poly aromatic hydrocarbons (PAHs) and corresponding methylated homologous series obtained by direct pyrolyisis (Py-GC/MS) of core sediments. The chromatogram is for sample 25T1 30-40 cm. Napth naphthalene, C1-Napth, methylnaphthalene, C2-Napth, dimethylnaphthalene, C3-Napth, trimethylnaphthalene, C4-Napth, tetramethylnaphthalene, $\mathrm{BiPh}$ Biphenyl, $\mathrm{C} 1-\mathrm{BiPh}$ methyl biphenyl, Flo fluorene, C1-Flo methyl fluorine, Carb carbazole, DBT dibenzothiophene, C1-DBT methyldibenzothiophene, BiPh biphenyl, C1-BiPh methylbiphenyl, Phe phenanthrene, C1-Phe methylphenanthrene, C2-Phe dimethylphenanthrene, Fluo fluoranthene, Pyr pyrene, C1-Pyr methylpyrene, C2-Pyr dimethylpyrene, Tphe triphenylene, PhNap 2-phenylnaphthalene, Ret retene

Here the presence of PAHs in the Ria Formosa lagoon sediments was studied by extracting their characteristic ions and an example is in Fig. 5. PAH relative abundances and a semi-quantitative assessment in the sediments studied can be found in Table 3. In general, the most abundant PAHs in the sediments were small molecules (2-3 rings), whereas methylsubstituted PAHs $\left(\mathrm{C}_{1}-\mathrm{C}_{4}\right)$ were detected at less abundance than the parent PAHs $\left(\mathrm{C}_{0}\right)$ homologues (Table 3). Besides, heterocyclic PAHs such as benzofuran, benzothiophene and carbazole were also identified. The biogenic PAH (retene) was also detected in sediment pyrolysates. This composition and the abundances of PAHs found points to contributions from natural as well as anthropogenic sources.

\section{Biogenic PAH (retene)}

Retene (1-methyl-7-isopropylphenanthrene) was the only naturally derived PAH compound identified, mainly in the more inland transects, present in $15 \mathrm{~T}$ and but mainly in $25 \mathrm{~T}$, where it is most abundant in the upper T1 core (Table 3; Fig. 5). Retene is a diagenesis product formed by a dehydrogenation and aromatization of the diterpenoid abietic acid, abundant in pine resin (Otto and Simoneit 2001). The occurrence of retene in the core sediments of the Ria Formosa points to contributions from the pine trees that are abundant in the catchment area and incorporated into sediments after the transport and diagenesis of resinous $\mathrm{OM}$. Retene can be also generated from anthropogenic activities and natural forest fires. Coniferous forest fires are very common in the Southwest Iberian Peninsula during the summer months. The atmospheric aerosols produced during wildfires in Portugal are known to contain a significant amount of retene (Alves et al. 2011); thus, wildfire-derived atmospheric aerosols could be an additional source of retene to the Ria Formosa core sediments. However, coniferous resins are not the only source for retene, and it is also known that algal and bacterial precursors are also possible sources (Wen et al. 2000).

\section{Anthropogenic PAHs}

The results illustrated that low molecular weight (2-3 rings) PAHs are predominant in the sediments of all transects. These unsubstituted (2-3 rings) PAHs (e.g., biphenyl, naphthalene and phenanthrene) were recorded with a very large relative abundance and larger than their corresponding methylated homologues (Table 3; Fig. 5). The 4- and 5-ring structure PAHs were less abundant. These compounds have a pyrogenic origin and usually produced by an incomplete combustion of fossils fuels, burning of biomass and forest fires. This material is emitted to the atmosphere as soot or gas and ultimately carried to terrestrial and aquatic environments through atmospheric fallout (González-Pérez et al. 2014; Alves et al. 2011). Additionally, vehicle exhausts and other combustion processes are a potential source of PAHs in the environment. Compounds that are usually attributed to petrogenic sources i.e. methylated homologous of naphthalene, phenanthrenes, fluorene and biphenyl (Yunker et al. 2002) were recorded in low abundance. Heterocyclic PAHs like fluorene, benzothiophene, dibenzothiophene, dibenzofuran, carbazole and methylated homologue are also present in the core sediment pyrolysates (Table 3), suggesting PAHs inputs from petrogenic sources (Peters et al. 2005) to the lagoon sediments. Our observation is supported by previous studies in Ria Formosa on the occurrence of PAHs in clam (Ruditapes decussatus) that were found to vary seasonally rather than spatially and associated with a mixture of petrogenic and pyrolytic sources (Barreira et al. 2007a).

Inputs of petrogenic PAHs to the coastal environments are usually anthropogenic and resulting from accidental discharges, such are the crude oil spillages from ship traffic or street drainage urban runoff with leaked petroleum products (Stout et al. 2001). Algarve (South coast of Portugal) and areas near Faro City are prone to oil spills and other potential sources of PAHs contamination; it is situated close to the passage of large ships along the Atlantic Ocean route, and the areas include several points and diffuse pollution sources from domestic, aquaculture sewage effluents and boat traffic. Besides, the Faro International Airport located in the proximity of the lagoon could be also a possible source of kerosene soot (Barreira et al. 2007b) and of other PAHs emissions from aircraft engines, ground vehicles and furnaces (Zielinska et al. 2004).

Very few studies have been conducted dealing with PAHs degradation and preservation in the sediments of salt marshes (Martins et al. 2008; Wang et al. 2012; Kumar et al. 2020). The microbial degradation is probably the main factor favouring PAH degeneration in the sediments. In salt marshes, the plant-mediated oxygenation of sediments, mainly in the root zone, has been observed (Martins et al. 2008) and below ground, oxygen diffusion to the surrounding sediment are believed to promote $\mathrm{PAH}$ degradation, specifically of the smaller molecules (Quantin et al. 2005; Martins et al. 2008).

Vegetated site core sediments in Ria Formosa hold a large relative abundance of 4- and 5-ring PAHs than tidal flats sites (Table 3). Martins et al. (2008) also reported larger 5- and 6- 
Table 3 Semiquantitative assessment of poly aromatic hydrocarbons (PAHs) and the corresponding methylated homologous series in the transect core sediments profiles

\begin{tabular}{|c|c|c|c|c|c|c|c|c|c|c|c|c|c|}
\hline & Core site & $\begin{array}{l}m / z \\
\text { Sediment depth }\end{array}$ & $\begin{array}{l}128 \\
\text { Napth }\end{array}$ & $\begin{array}{l}142 \\
\text { C1- } \\
\text { Napth }\end{array}$ & $\begin{array}{l}156 \\
\text { C2- } \\
\text { Napth }\end{array}$ & $\begin{array}{l}170 \\
\text { C3- } \\
\text { Napth }\end{array}$ & $\begin{array}{l}184 \\
\text { C4- } \\
\text { Napth }\end{array}$ & $\begin{array}{l}154 \\
\mathrm{BiPh}\end{array}$ & $\begin{array}{l}168 \\
\text { Dphm }\end{array}$ & $\begin{array}{l}166 \\
\text { Flo }\end{array}$ & $\begin{array}{l}180 \\
\text { C1- } \\
\text { Flo }\end{array}$ & $\begin{array}{l}167 \\
\text { Carb }\end{array}$ & $\begin{array}{l}178 \\
\text { Phe }\end{array}$ \\
\hline \multirow{9}{*}{$\begin{array}{l}5 \mathrm{~T} \\
\text { tran- } \\
\text { sect }\end{array}$} & \multirow{3}{*}{$\begin{array}{l}\text { T1 (Sarcocornia } \\
\quad \text { fruticosa) }\end{array}$} & $5 \mathrm{~T} 10-10 \mathrm{~cm}$ & + & $+/-$ & $+/-$ & $+/-$ & $+/-$ & +++ & + & ++ & + & $+/-$ & ++ \\
\hline & & $5 \mathrm{~T} 130-40 \mathrm{~cm}$ & +++ & +++ & + & $+/-$ & $+/-$ & +++ & + & ++ & + & - & ++ \\
\hline & & BT1 90-100 cm & ++ & + & $+/-$ & $+/-$ & $+/-$ & $+/-$ & $+/-$ & $+/-$ & $+/-$ & - & $+/-$ \\
\hline & \multirow{3}{*}{$\begin{array}{c}\mathrm{T} 2 \text { (Spartina } \\
\text { maritima })\end{array}$} & $5 \mathrm{~T} 20-10 \mathrm{~cm}$ & ++ & + & $+/-$ & $+/-$ & $+/-$ & $+/-$ & $+/-$ & $+/-$ & $+/-$ & - & $+/-$ \\
\hline & & $5 \mathrm{~T} 230-40 \mathrm{~cm}$ & +++ & ++ & + & $+/-$ & $+/-$ & + & $+/-$ & + & $+/-$ & - & + \\
\hline & & $5 \mathrm{~T} 290-100 \mathrm{~cm}$ & ++ & $+/-$ & $+/-$ & $+/-$ & $+/-$ & $+/-$ & - & - & - & - & - \\
\hline & \multirow[t]{3}{*}{ T3 (Mudflat) } & $5 \mathrm{~T} 30-10 \mathrm{~cm}$ & $+/-$ & - & - & - & - & - & - & - & - & - & - \\
\hline & & $5 \mathrm{~T} 330-40 \mathrm{~cm}$ & +++ & +++ & + & + & + & ++ & + & ++ & + & - & $+/-$ \\
\hline & & $5 T 390-100 \mathrm{~cm}$ & ++ & + & $+/-$ & $+/-$ & $+/-$ & + & $+/-$ & $+/-$ & $+/-$ & - & $+/-$ \\
\hline \multirow{9}{*}{$\begin{array}{l}15 \mathrm{~T} \\
\text { tran- } \\
\text { sect }\end{array}$} & \multirow{3}{*}{$\begin{array}{l}\text { T1 (Sarcocornia } \\
\quad \text { fruticosa) }\end{array}$} & $15 \mathrm{~T} 10-10 \mathrm{~cm}$ & +++ & +++ & ++ & ++ & + & +++ & ++ & +++ & ++ & + & +++ \\
\hline & & $15 \mathrm{~T} 130-40 \mathrm{~cm}$ & - & - & - & - & - & - & - & & - & - & - \\
\hline & & $15 \mathrm{~T} 190-100 \mathrm{~cm}$ & - & - & - & - & - & - & - & - & - & - & - \\
\hline & \multirow{3}{*}{$\begin{array}{c}\mathrm{T} 2(\text { Spartina } \\
\text { maritima })\end{array}$} & $15 \mathrm{~T} 20-10 \mathrm{~cm}$ & +++ & +++ & ++ & + & + & +++ & + & +++ & ++ & + & ++ \\
\hline & & $15 \mathrm{~T} 230-40 \mathrm{~cm}$ & +++ & ++ & + & + & + & ++ & $+/-$ & + & $+/-$ & - & + \\
\hline & & $15 \mathrm{~T} 290-100 \mathrm{~cm}$ & ++ & + & $+/-$ & $+/-$ & $+/-$ & + & $+/-$ & $+/-$ & $+/-$ & - & $+/-$ \\
\hline & \multirow[t]{3}{*}{ T3 (Mudflat) } & $15 \mathrm{~T} 30-10 \mathrm{~cm}$ & +++ & +++ & ++ & + & + & +++ & + & ++ & + & + & ++ \\
\hline & & $15 \mathrm{~T} 330-40 \mathrm{~cm}$ & +++ & +++ & ++ & ++ & + & +++ & + & +++ & + & + & ++ \\
\hline & & $15 T 390-100 \mathrm{~cm}$ & +++ & +++ & ++ & ++ & + & +++ & + & +++ & + & $+/-$ & ++ \\
\hline \multirow{11}{*}{$\begin{array}{l}25 \mathrm{~T} \\
\text { tran- } \\
\text { sect }\end{array}$} & \multirow{3}{*}{$\begin{array}{l}\text { T1 (Sarcocornia } \\
\quad \text { fruticosa) }\end{array}$} & $25 \mathrm{~T} 10-10 \mathrm{~cm}$ & +++ & +++ & ++ & ++ & + & +++ & + & +++ & ++ & ++ & +++ \\
\hline & & $25 \mathrm{~T} 130-40 \mathrm{~cm}$ & +++ & +++ & ++ & ++ & + & +++ & + & + & $+/-$ & +++ & +++ \\
\hline & & $25 \mathrm{~T} 190-100 \mathrm{~cm}$ & +++ & +++ & ++ & + & + & +++ & + & +++ & ++ & + & ++ \\
\hline & \multirow{3}{*}{$\begin{array}{c}\mathrm{T} 2 \text { (Spartina } \\
\text { maritima) }\end{array}$} & $25 \mathrm{~T} 20-10 \mathrm{~cm}$ & +++ & +++ & ++ & + & + & +++ & + & +++ & ++ & ++ & +++ \\
\hline & & $25 \mathrm{~T} 230-40 \mathrm{~cm}$ & +++ & +++ & ++ & + & + & +++ & + & +++ & ++ & $+/-$ & ++ \\
\hline & & $25 \mathrm{~T} 290-100 \mathrm{~cm}$ & +++ & ++ & + & $+/-$ & $+/-$ & ++ & $+/-$ & + & $+/-$ & $+/-$ & + \\
\hline & \multirow[t]{5}{*}{ T3 Core (Mudflat) } & $25 \mathrm{~T} 30-10 \mathrm{~cm}$ & +++ & +++ & ++ & + & + & +++ & + & ++ & + & + & ++ \\
\hline & & $25 \mathrm{~T} 330-40 \mathrm{~cm}$ & +++ & +++ & ++ & + & + & +++ & + & +++ & ++ & ++ & +++ \\
\hline & & $25 \mathrm{~T} 390-100 \mathrm{~cm}$ & +++ & +++ & + & + & + & ++ & + & ++ & + & $+/-$ & ++ \\
\hline & & & $m / z$ & 192 & 206 & 184 & 198 & 202 & 216 & 230 & 204 & 230 & 234 \\
\hline & & Core site & $\begin{array}{l}\text { Sediment } \\
\text { depth }\end{array}$ & C1-Phe & C2-Phe & DBT & C1-DBT & Pyr & C1-Pyr & C2-Pyr & PhNap & Tphe & Ret \\
\hline \multirow{8}{*}{\multicolumn{2}{|c|}{$5 \mathrm{~T}$ transect }} & \multirow[t]{3}{*}{$\begin{array}{l}\text { T1 (Sarcocornia } \\
\quad \text { fruticosa) }\end{array}$} & $\begin{array}{l}5 \mathrm{~T} 1 \\
\quad 0-10 \mathrm{~cm}\end{array}$ & $+/-$ & - & - & - & $+/-$ & - & - & $+/-$ & - & - \\
\hline & & & $\begin{array}{l}5 \mathrm{~T} 1 \\
\quad 30-40 \mathrm{c}- \\
\mathrm{m}\end{array}$ & - & - & $+/-$ & - & $+/-$ & - & - & $+/-$ & - & - \\
\hline & & & $\begin{array}{l}\text { BT1 } \\
\quad 90-100 \\
\text { cm }\end{array}$ & - & - & - & - & - & - & - & - & - & - \\
\hline & & \multirow[t]{3}{*}{$\begin{array}{c}\mathrm{T} 2 \text { (Spartina } \\
\text { maritima })\end{array}$} & $\begin{array}{l}5 \mathrm{~T} 2 \\
\quad 0-10 \mathrm{~cm}\end{array}$ & - & - & - & - & - & - & - & - & - & - \\
\hline & & & $\begin{array}{l}5 \mathrm{~T} 2 \\
\quad 30-40 \mathrm{c}- \\
\mathrm{m}\end{array}$ & - & - & - & - & $+/-$ & - & - & - & - & - \\
\hline & & & $\begin{array}{l}5 \mathrm{~T} 2 \\
\quad 90-100 \\
\mathrm{~cm}\end{array}$ & - & - & - & - & - & - & - & - & - & - \\
\hline & & \multirow[t]{2}{*}{ T3 (Mudflat) } & $\begin{array}{l}5 \mathrm{~T} 3 \\
\quad 0-10 \mathrm{~cm}\end{array}$ & - & - & - & - & - & - & - & - & - & - \\
\hline & & & $\begin{array}{l}5 \mathrm{~T} 3 \\
\quad 30-40 \mathrm{c}- \\
\mathrm{m}\end{array}$ & - & - & - & - & $+/-$ & - & - & $+/-$ & - & - \\
\hline
\end{tabular}


Table 3 (continued)

\begin{tabular}{|c|c|c|c|c|c|c|c|c|c|c|c|c|}
\hline Core site & $\begin{array}{l}m / z \\
\text { Sediment depth }\end{array}$ & $\begin{array}{l}128 \\
\text { Napth }\end{array}$ & $\begin{array}{l}142 \\
\text { C1- } \\
\text { Napth }\end{array}$ & $\begin{array}{l}156 \\
\text { C2- } \\
\text { Napth }\end{array}$ & $\begin{array}{l}170 \\
\text { C3- } \\
\text { Napth }\end{array}$ & $\begin{array}{l}184 \\
\text { C4- } \\
\text { Napth }\end{array}$ & $\begin{array}{l}154 \\
\mathrm{BiPh}\end{array}$ & $\begin{array}{l}168 \\
\text { Dphm }\end{array}$ & $\begin{array}{l}166 \\
\text { Flo }\end{array}$ & $\begin{array}{l}180 \\
\text { C1- } \\
\text { Flo }\end{array}$ & $\begin{array}{l}167 \\
\text { Carb }\end{array}$ & $\begin{array}{l}178 \\
\text { Phe }\end{array}$ \\
\hline & & $\begin{array}{l}5 \mathrm{~T} 3 \\
\quad 90-100 \\
\mathrm{~cm}\end{array}$ & - & - & - & - & - & - & - & - & - & - \\
\hline \multirow[t]{9}{*}{$15 \mathrm{~T}$ transect } & $\begin{array}{l}\mathrm{T} 1 \text { (Sarcocornia } \\
\text { fruticosa) }\end{array}$ & $\begin{array}{l}15 \mathrm{~T} 1 \\
\quad 0-10 \mathrm{~cm}\end{array}$ & ++ & + & - & - & + & $+/-$ & - & + & - & - \\
\hline & & $\begin{array}{l}15 \mathrm{~T} 1 \\
30-40 \mathrm{c}- \\
\mathrm{m}\end{array}$ & - & - & - & - & - & - & - & - & - & - \\
\hline & & $\begin{array}{l}15 \mathrm{~T} 1 \\
90-100 \\
\mathrm{~cm}\end{array}$ & - & - & - & - & - & - & - & - & - & - \\
\hline & $\begin{array}{c}\mathrm{T} 2 \text { (Spartina } \\
\text { maritima })\end{array}$ & $\begin{array}{l}15 \mathrm{~T} 2 \\
0-10 \mathrm{~cm}\end{array}$ & + & + & - & - & + & $+/-$ & - & + & - & + \\
\hline & & $\begin{array}{l}15 \mathrm{~T} 2 \\
30-40 \mathrm{c}- \\
\mathrm{m}\end{array}$ & - & - & $+/-$ & - & $+/-$ & - & - & $+/-$ & - & - \\
\hline & & $\begin{array}{l}15 \mathrm{~T} 2 \\
\quad 90-100 \\
\mathrm{~cm}\end{array}$ & - & - & - & - & $+/-$ & - & - & - & - & - \\
\hline & T3 (Mudflat) & $\begin{array}{l}15 \mathrm{~T} 3 \\
0-10 \mathrm{~cm}\end{array}$ & - & - & - & - & $+/-$ & $+/-$ & - & + & $+/-$ & + \\
\hline & & $\begin{array}{l}15 \mathrm{~T} 3 \\
30-40 \mathrm{c}- \\
\mathrm{m}\end{array}$ & - & - & + & - & $+/-$ & $+/-$ & - & $+/-$ & - & - \\
\hline & & $\begin{array}{l}15 \mathrm{~T} 3 \\
90-100 \\
\mathrm{~cm}\end{array}$ & - & - & + & $+/-$ & $+/-$ & $+/-$ & - & $+/-$ & - & $+/-$ \\
\hline \multirow[t]{9}{*}{$25 \mathrm{~T}$ transect } & $\begin{array}{l}\text { T1 (Sarcocornia } \\
\text { fruticosa) }\end{array}$ & $\begin{array}{l}25 \mathrm{~T} 1 \\
\quad 0-10 \mathrm{~cm}\end{array}$ & + & + & + & + & + & $+/-$ & - & +++ & +++ & +++ \\
\hline & & $\begin{array}{l}25 \mathrm{~T} 1 \\
\quad 30-40 \mathrm{c}- \\
\mathrm{m}\end{array}$ & ++ & ++ & ++ & ++ & ++ & + & - & +++ & ++ & +++ \\
\hline & & $\begin{array}{l}25 \mathrm{~T} 1 \\
\quad 90-100 \\
\mathrm{~cm}\end{array}$ & + & + & + & + & + & $+/-$ & $+/-$ & + & + & ++ \\
\hline & $\begin{array}{c}\mathrm{T} 2 \text { (Spartina } \\
\text { maritima })\end{array}$ & $\begin{array}{l}25 \mathrm{~T} 2 \\
\quad 0-10 \mathrm{~cm}\end{array}$ & ++ & + & + & + & + & $+/-$ & $+/-$ & ++ & + & + \\
\hline & & $\begin{array}{l}25 \mathrm{~T} 2 \\
\quad 30-40 \mathrm{c}- \\
\mathrm{m}\end{array}$ & - & - & ++ & + & + & $+/-$ & - & + & $+/-$ & + \\
\hline & & $\begin{array}{l}25 \mathrm{~T} 2 \\
\quad 90-100 \\
\mathrm{~cm}\end{array}$ & - & - & - & - & $+/-$ & - & - & $+/-$ & - & - \\
\hline & T3 Core (Mudflat) & $\begin{array}{l}25 \mathrm{~T} 3 \\
\quad 0-10 \mathrm{~cm}\end{array}$ & - & - & + & + & + & $+/-$ & - & + & + & + \\
\hline & & $\begin{array}{l}25 \mathrm{~T} 3 \\
\quad 30-40 \mathrm{c}- \\
\mathrm{m}\end{array}$ & - & - & ++ & ++ & + & $+/-$ & - & + & - & + \\
\hline & & $\begin{array}{l}25 \mathrm{~T} 3 \\
\quad 90-100 \\
\mathrm{~cm}\end{array}$ & - & - & + & + & $+/-$ & $+/-$ & - & $+/-$ & - & - \\
\hline
\end{tabular}

Napth naphthalene, C1-Napth methylnaphthalene, C2-Napth dimethylnaphthalene, C3-Napth trimethylnaphthalene, C4-Napth tetramethylnaphthalene, Flo fluorene, Carb carbazole, DBT dibenzothiophene, C1-DBT methyldibenzothiophene, BiPh biphenyl, Dphm diphenylmethane, Phe phenanthrene, C1-Phe methylphenanthrene, C2-Phe dimethylphenanthrene, Fluo fluoranthene, Pyr pyrene, C1-Pyr methylpyrene, C2-Pyr dimethylpyrene, Tphe triphenylene, PhNap 2-phenylnaphthalene, Ret retene

Semiquantitative assessment: (+++) most abundant; (++) abundant; (+) present; (+/-) trace; (-) not detected 
Fig. 6 Mass chromatogram of lineal alkyl benzenes (LABs) series $(m / z, 92)$ obtained by direct pyrolysis (Py-GC/MS) of the sediment. The chromatogram is for sample 25T3 $30-40 \mathrm{~cm}$

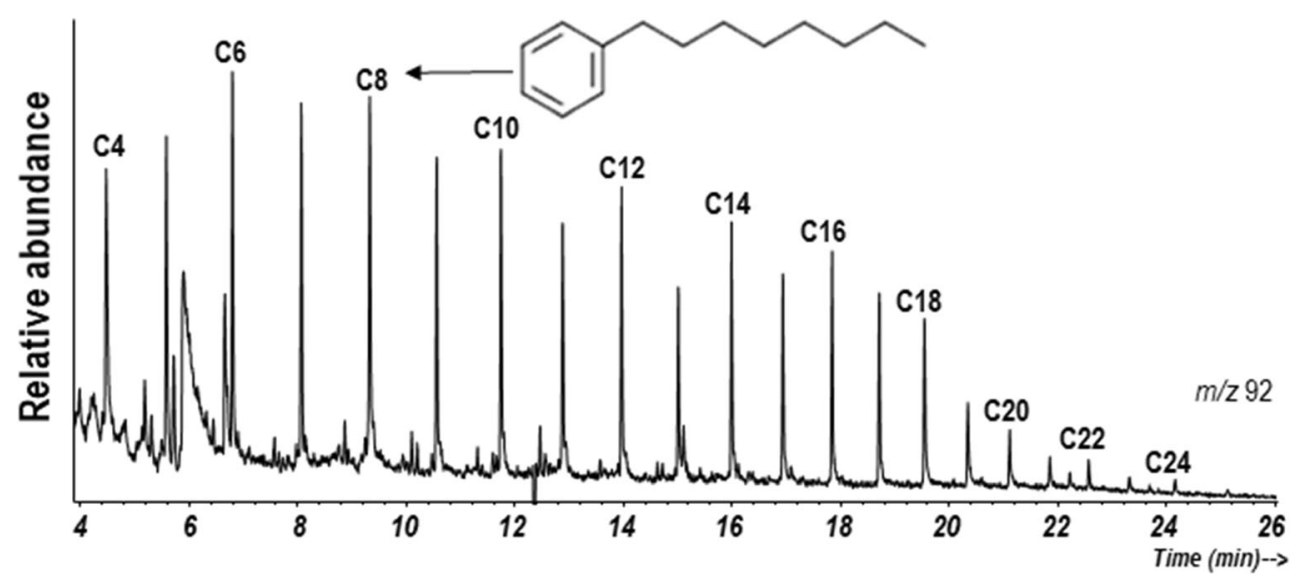

ring PAHs contents in salt marsh sediments colonized by Sarcocornia fruticosa than in non-colonized. This was attributed to the hydrophobic nature of PAHs in a phasepartitioning or -distribution system favouring its preferential adsorption to the rooted sediments organic matter (Liste and Alexander 2000). The previous study on sources of PAHs in sediments from Ria Formosa lagoon by Barreira et al. (2007a) showed that PAH concentrations are linked to a seasonal variation. The distribution of the 4-ring PAHs in January was the most abundant, while in the other months, 2- and 3-ring PAHs were most abundant.

\section{LABs}

Linear alkylbenzenes (LABs) are used in the synthesis of linear alkylbenzene sulfonates (LAS), anionic surfactants usually used in commercial detergents. Therefore, in the aquatic environments, the presence of LABs is mainly due to carryover in detergents and/or by desulphonation of LAS and final discharge to the aquatic environment. The LABs are hydrophobic substances that easily adsorb to organic-rich particulate matter and accumulate in the sediments (Sherblom et al. 1992). Furthermore, LABs are persistent compounds frequently found in the sediments from marine and coastal environments (Sherblom et al. 1992; Isobe et al. 2004; Terán et al. 2009). It has been reported that the LABs may persist for more than 20 years in anaerobic conditions, (Heim et al. 2004). Eganhouse and Pontolillo (2008) reported a half-life time for LABs in the sediments in the range of 8 to 11 years and proposed the use of LABs as molecular markers surrogated to domestic waste input to sedimentary OM.

A search for the diagnostic fragment ion $\mathrm{m} / \mathrm{z} 92$ full series of LABs was identified in the Ria Formosa core sediment pyrolysate-based mass chromatogram. An example for this is shown in Fig. 6, and a semi-quantitative study of the LABs found is given in Table 4. The substituted benzenes with alkyl chains ranging from $\mathrm{C}_{4}$ to $\mathrm{C}_{23}$ were detected in all samples but in two samples from transect 15T (T1 30-40 and 90-100 cm). The molecular distribution of LABs in the sediments was dominated by the short-chain structures in the range $\mathrm{C}_{4}-\mathrm{C}_{15}$. The relative distribution of $\mathrm{LABs}$ in all three transect core sediments did not exhibit noticeable variations in the core samples from different regions of Ria Formosa, probably due to limited degradation processes. Long-chain LABs accumulation in sediments predominates over short-chain because the octanol-water partition coefficient usually increases with chain length enlargement (Sherblom et al. 1992). Therefore, the dominance of $\mathrm{C}_{12}$ and $\mathrm{C}_{13}$ chain length LABs observed in most sediments points to low degradation and to possible discharges to the lagoon of inadequately or uncompleted treated sewage. All this produced the accumulation of long-chain homologues observed in the Ria Formosa lagoon sediments. Although, other factors may be also involved in the observed accumulation of long chain LABs, including the sediment organic carbon content, anaerobic conditions and eutrophic conditions (Takada and Ishiwatari 1990). Ria Formosa lagoon is subjected to eutrophication (Newton et al. 2003) and LABs' preservation in deeper sedimentary profiles can be explained by (1) continuous inputs of LABs to the lagoon from diffuse and non-diffuse sources such as hospitals, hotels and restaurants where human activities are intense and (2) LABs are hydrophobic and often associated with the particulate organic matter in sewage that is quickly incorporated into the bottom sediments (Sherblom et al. 1992). The LABs series found here is in line and agrees with a previous study in salt marsh sediments of the nearby Guadiana estuary (Terán et al. 2009) and, in general, indicate the occurrence of untreated sewage influx to the Ria Formosa lagoon from adjacent urban areas.

\section{Steranes}

Regular steranes and diasteranes were identified in core sediments from both $15 \mathrm{~T}$ and $25 \mathrm{~T}$ transects. Regular steranes were identified by mass chromatograms $(\mathrm{m} / \mathrm{z} 217)$. To acquire a better distribution of the diasteranes, selected-ion monitoring 


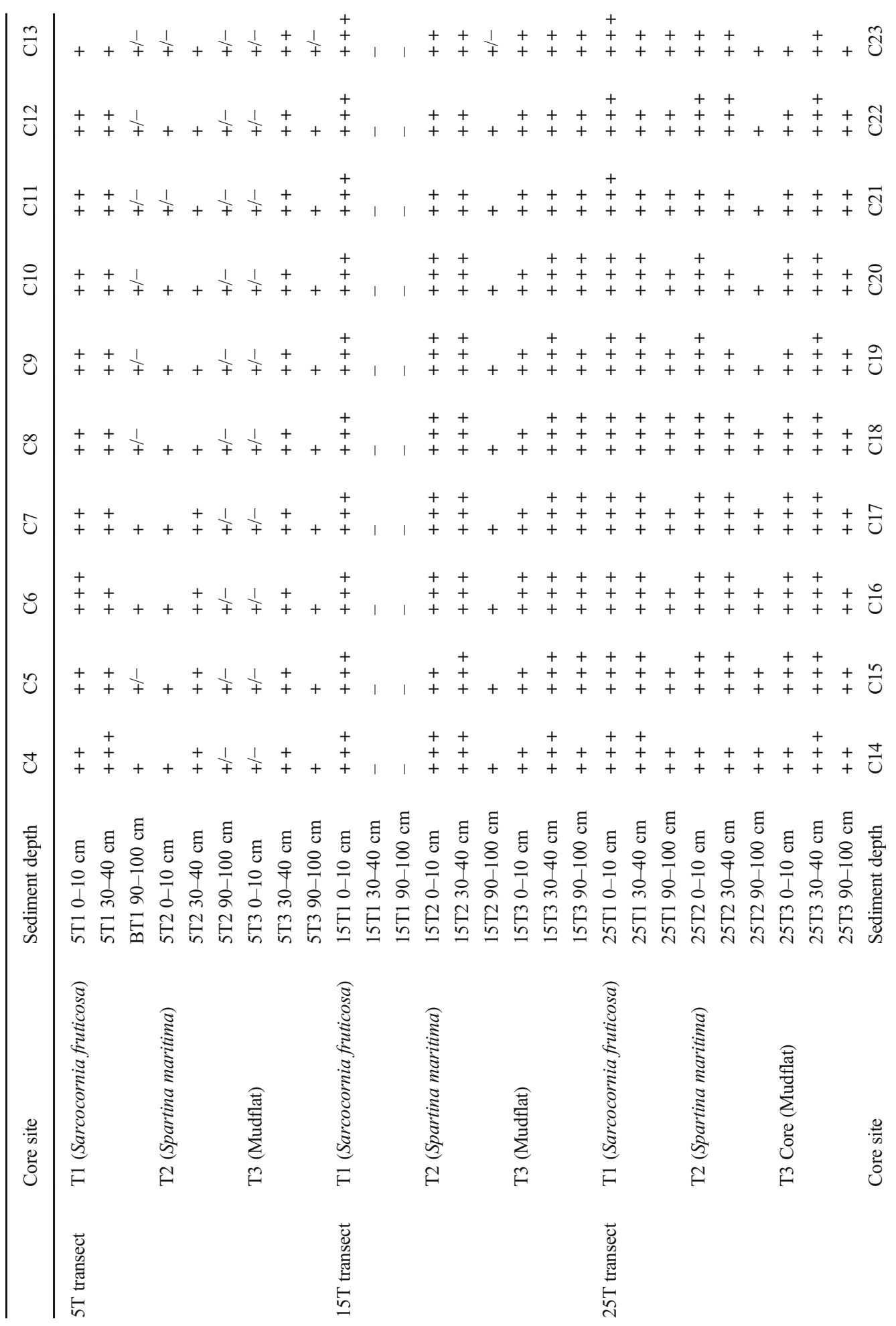

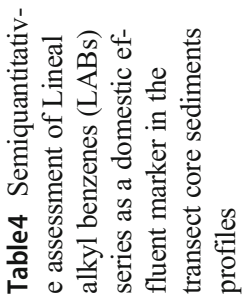




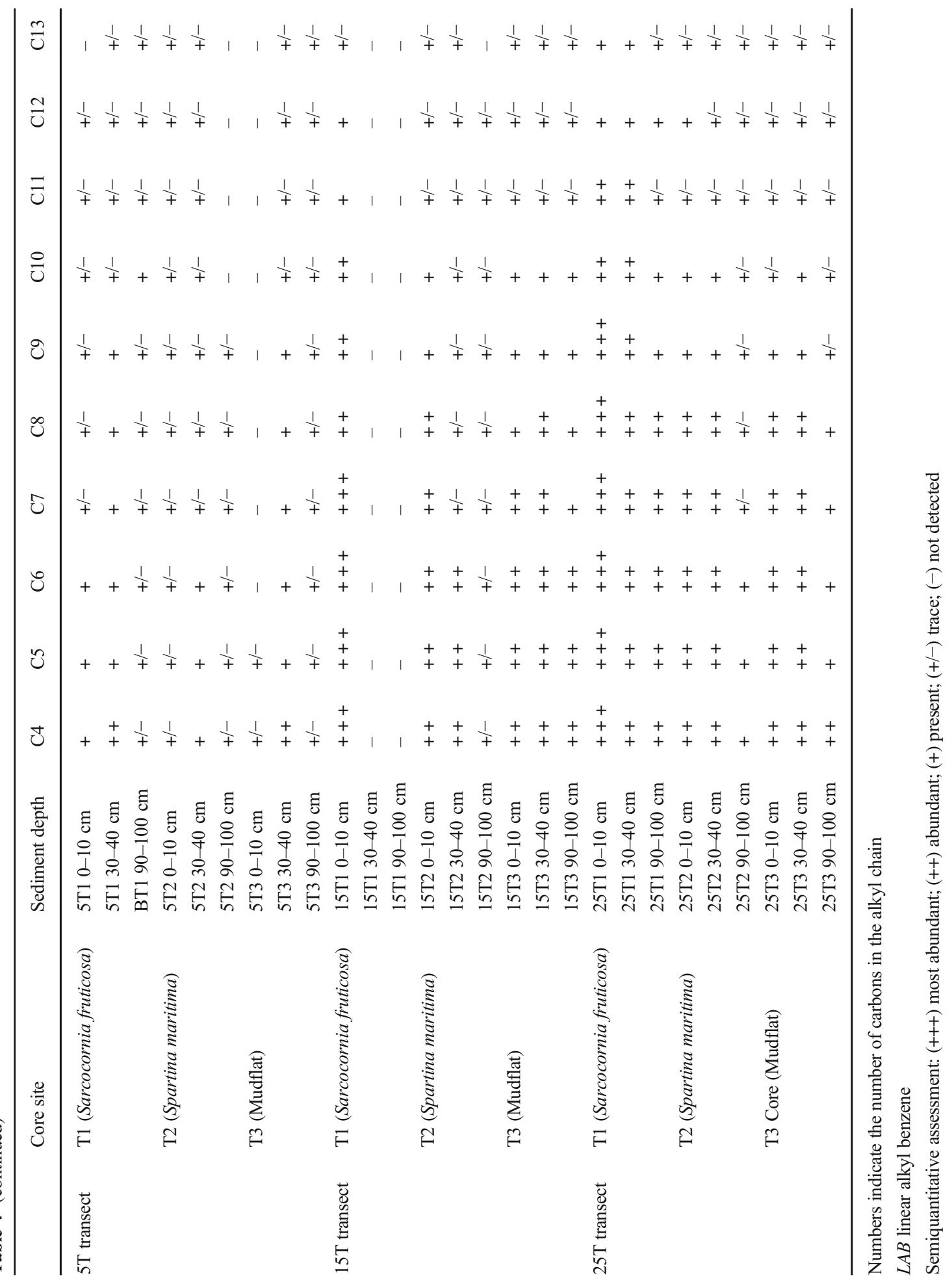



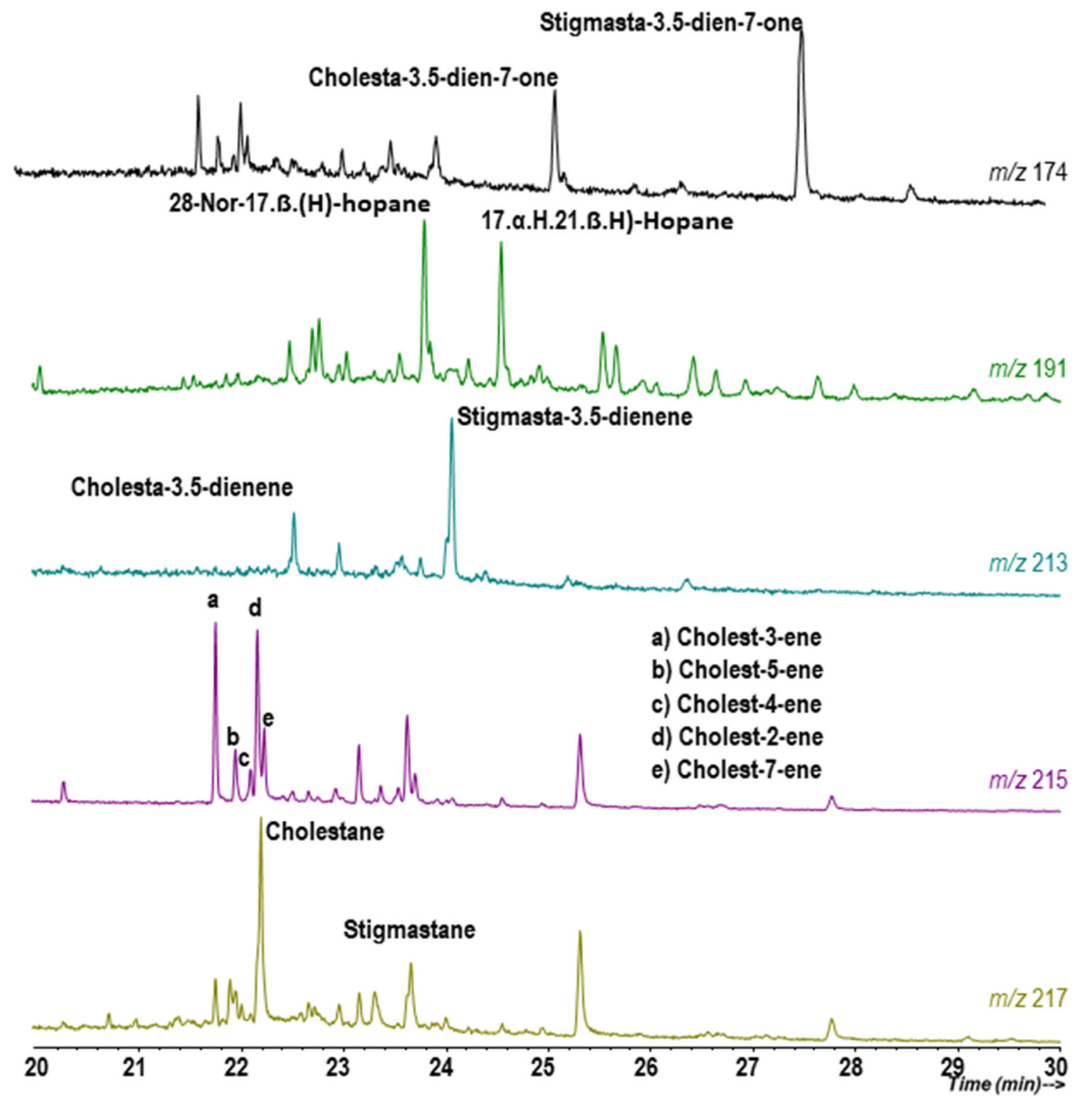

Fig. 7 Ion chromatograms for steranes $(\mathrm{m} / \mathrm{z}, 217)$, diasteranes $(\mathrm{m} / \mathrm{z}, 215, \mathrm{~m} / \mathrm{z} 213$ and $\mathrm{m} / \mathrm{z}, 174)$ and hopanes $(\mathrm{m} / \mathrm{z}, 191)$ obtained by direct pyrolysis (Py$\mathrm{GC} / \mathrm{MS})$ of the sediments. Sample chromatogram for $25 \mathrm{~T} 130-40 \mathrm{~cm}$

chromatograms at $m / z 215,213,211$ and 174 were performed. An example of a sediment single ion monitoring chromatogram with the relative distribution of the studied steranes is in Fig. 7.

Sediment samples contained a series of regular sterane $\left(\mathrm{C}_{27}-\mathrm{C}_{29}\right)$ biomarker with a predominance of the $\mathrm{C}_{27}$ homologues. The abundances of steranes are useful indicators of qualitative changes in the biological $\mathrm{OM}$ input sources (Huang and Meinschein 1979). The predominance of $C_{27}$ steranes suggests plankton/algal and bacterial-derived OM input, while contributions from terrigenous organic show larger $\mathrm{C}_{29}$ steranes (Huang and Meinschein 1979), but this interpretation has many exceptions. Although, terrestrial plants are known major sources of $\mathrm{C}_{29}$ steranes, several microalgae and particularly freshwater cyanobacteria and marine algae diatoms and dinoflagellates are also known to contain large proportions of $\mathrm{C}_{29}$ sterols (Volkman 1986; Grantham 1986; Rampen et al. 2010). Studies also have indicated that there are examples of crude oils contaminated coastal sediments that contain $\mathrm{C}_{27}$ and $\mathrm{C}_{29}$ steranes in large abundance but not sourced from terrestrial OM (Grantham 1986; Aboul-Kassim and Simoneit 1996).

The OM diagenesis in coastal sediments also modifies steroid precursor structures in several ways. The diagenetic 


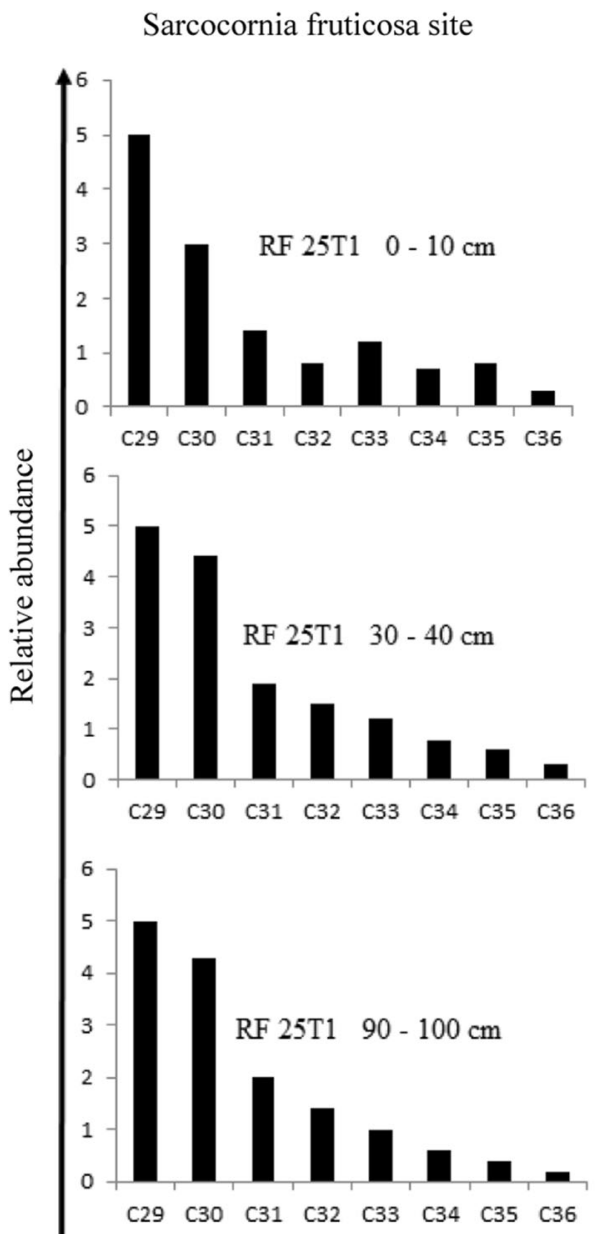

Spartina maritima site
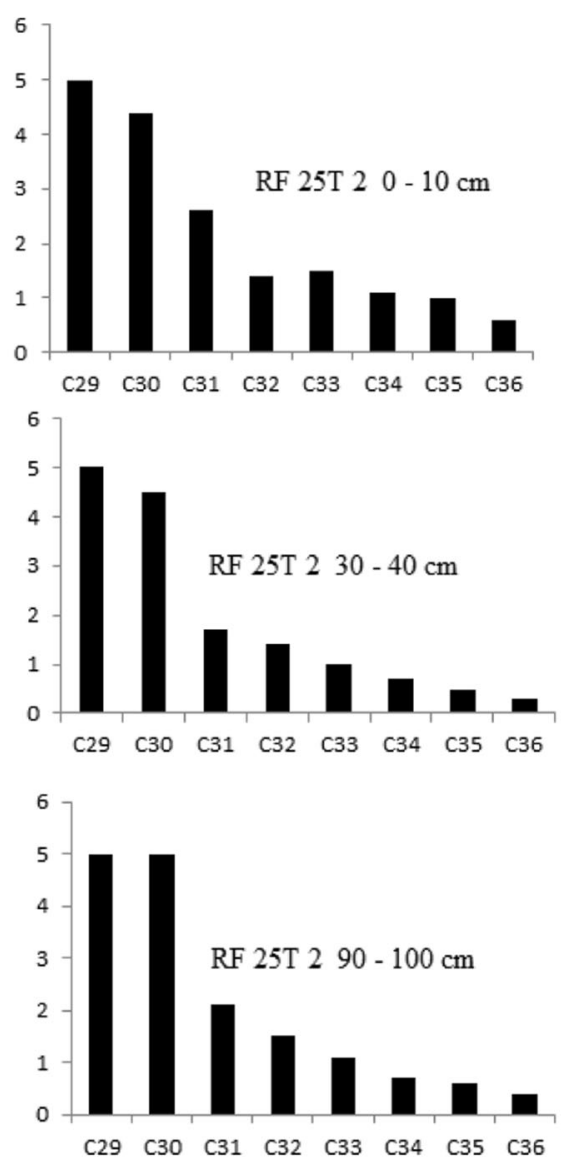

Mudflat site
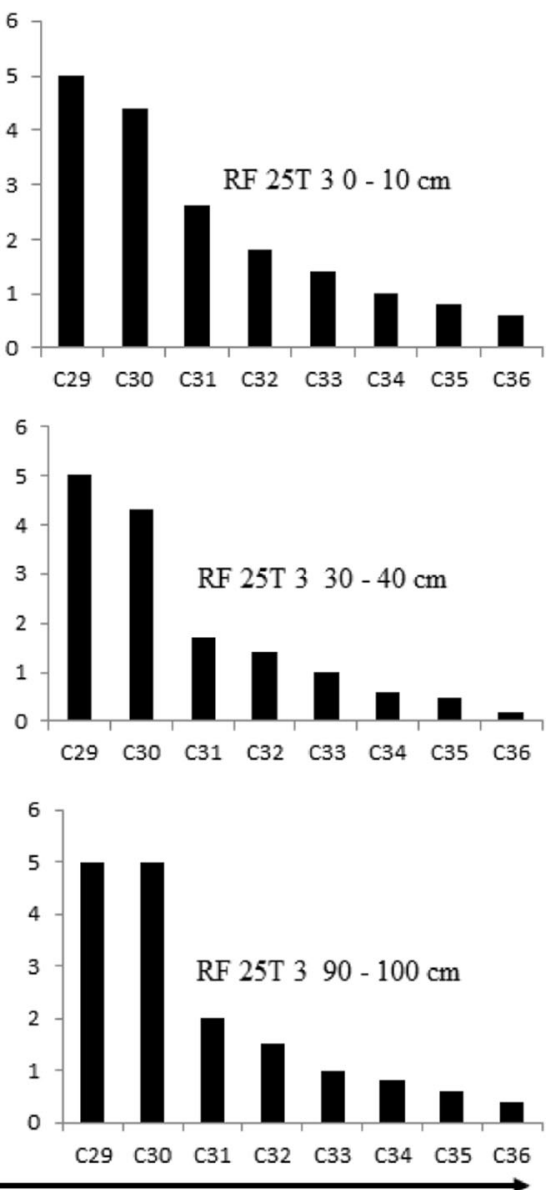

Time (min)

Fig. 8 Histograms of hopane biomarkers series $(\mathrm{m} / \mathrm{z}, 191)$ obtained by direct pyrolysis (Py-GC/MS) of the sediments. Example for sediments in transect $25 \mathrm{~T}$

dehydration of sterols leads to the formation of unsaturated steranes (sterenes and steradienes) (Mackenzie et al. 1982; Brassell et al. 1984; Kumar et al. 2019). The unsaturated sterane series found here is well in line with previous studies from Santa Olalla lagoon (SW Iberian Peninsula, Spain) (Grimalt et al. 1991). Our observation is also consistent with the previous research on SW Iberian Peninsula sedimentary humic acids (De la Rosa et al. 2011) that identified cholest-3ene, cholesta-3, 5-diene and stigmastan-3, 5-diene in surface sediment pyrolysates. However, unsaturated sterenes $\left(\mathrm{C}_{27}\right.$ and $\mathrm{C}_{29}$ ) and steroidal ketones (stigmasta-3, 5-dien7-one and stigmast-4-en-3-one) have been also reported to occur from the combustion of biomass from conifers plants and forest fires (Alves et al. 2011). Thus, aerosols derived from forest fire could be an alternative source of unsaturated sterenes in Ria Formosa salt marsh sediments. Overall, the distribution of steranes and diasteranes in Ria Formosa core sediments reflect inputs of OM derived from multiple sources including algae, terrestrial plants and probably also soot from forest fires.

\section{Hopanes}

The hopane biomarker series were identified by monitoring the diagnostic fragment at $\mathrm{m} / z$ 191. A noticeable series of $C_{29}$ to $C_{36}$ hopanes was found in core sediment pyrolysates, characterized by the predominance of $\mathrm{C}_{29}$ homologue with a step progression from $\mathrm{C}_{29}-\mathrm{C}_{36}$ hopanes (Figs. 7 and 8). Hopane series relative abundance was invariant with increasing depth in the core profiles. Hopane biomarkers composition differs in crude oils depending on their origin from source rock (depositional environment and sources of OM) and crude oil maturity status (Peters and Moldowan 1991). Hopane biomarkers are highly source-specific and persistent in the environment and, thus, useful to trace petrogenic contamination in coastal sediments regardless of the presence of other biogenic compounds (Bouloubassi et al. 2001). The uniform composition of hopanes observed in all analysed sediments in this study indicates inputs from a single source. Furthermore, this hopane biomarkers assemblage can be related to that in crude oil from the Middle East (Zakaria et al. 2001). Previous observation from Portuguese coastal 
sediments (mainly from beaches) has suggested a similar hopane composition to that found here and in the range $\mathrm{C}_{31}$ to $\mathrm{C}_{35}$ and with a predominance of the $\mathrm{C}_{29}$ homologue (Mizukawa et al. 2013).

\section{Conclusions}

- Py-GC/MS-determined biomarkers demonstrate that the origin and distribution of natural $\mathrm{OM}$ in core sediments of Ria Formosa are considerably influenced by algal, bacterial and aquatic macrophytes, with little contribution from terrestrial inputs.

- The lignin-derived methoxyphenols recalcitrant component of OM attributed to core sediments profiles are derived from both angiosperm and gymnosperm plants. Methoxyphenols compositions reflect that grass type lignin (salt marshes and seagrass) was dominant in the sediment pyrolysates.

- Retene was abundant in two transects from Ria Formosa marshes pointing to OM inputs from pine trees.

- The presence of UCM, PAHs, hopanes, steranes and LABs suggest that Ria Formosa sediment is affected by petroleum/oil spills and domestic sewage pollution. This information is expected to facilitate effective controls and mitigation of domestic sewage and PAHs inputs.

- Distribution and abundance of LABs indicated substantial sewage pollution in Ria Formosa lagoon. The sewage treatment systems in the vicinity of the lagoon are insufficient/poorly performing and call for technological improvements.

- This study demonstrates that Py-GC/MS is a direct and effective tool for a fast screening for natural $\mathrm{OM}$ as well as contaminants in sediments without the use of hazardous solvents.

Acknowledgements The authors gratefully acknowledge Dr. Joaquín Delgado and Dr. Carlos Sousa for their help during core sediment sampling. Ms. Alba Carmona Navarro and Ms. Desire Monís Carrere are thanked for technical assistance.

Funding information The authors received funding from EU Erasmus Mundus Joint Doctorate fellowship (FUECA, University of Cadiz, Spain) for Mukesh Kumar. The research was supported by EU contract numbers FP7-ENV-2011, Grant agreement no: 282845 and FP7- 534 ENV-2012 Grant agreement no: 308392 and also from MINECO project INTERCARBON (CGL2016-78937-R).

\section{References}

Aboul-Kassim TA, Simoneit BR (1995) Petroleum hydrocarbon fingerprinting and sediment transport assessed by molecular biomarker and multivariate statistical analyses in the Eastern Harbour of Alexandria, Egypt. Mar Pollut Bull 30:63-73

Aboul-Kassim TA, Simoneit BR (1996) Lipid geochemistry of surficial sediments from the coastal environment of Egypt I. Aliphatic hydrocarbons-characterization and sources. Mar Chem 54:135-158
Allan J, Douglas AG (1977) Variations in the content and distribution of $n$-alkanes in a series of Carboniferous vitrinites and sporinites of bituminous rank. Geochim Cosmochim Acta 41:1223-1230

Aller RC, Cochran JK (2019) The critical role of bioturbation for particle dynamics, priming potential, and organic $\mathrm{C}$ remineralization in marine sediments: local and basin scales. Front Earth Sci 7:157. https:// doi.org/10.3389/feart.2019.00157

Alves CA, Vicente A, Monteiro C, Gonçalves C, Evtyugina M, Pio C (2011) Emission of trace gases and organic components in smoke particles from a wildfire in a mixed-evergreen forest in Portugal. Sci Total Environ 409:466-1475

Andrade C, Freitas MDC, Moreno J, Craveiro SC (2004) Stratigraphical evidence of Late Holocene barrier breaching and extreme storms in lagoonal sediments of Ria Formosa, Algarve, Portugal. Mar Geol 210:339-362

Barreira LA, Mudge SM, Bebianno MJ (2007a) Polycyclic aromatic hydrocarbons in clams Ruditapes decussatus (Linnaeus, 1758). J Environ Monit 9:187-198

Barreira LA, Mudge SM, Bebianno MJ (2007b) Concentration and sources of polycyclic aromatic hydrocarbons in sediments from the Ria Formosa lagoon. Environ Forensic 8:231-243

Bebianno MJ (1995) Effects of pollutants in the Ria Formosa lagoon, Portugal. Sci Total Environ 171:107-115

Boski T, Pessoa J, Pedro P, Thorez J, Hall I, Alveirinho Dias J (1998) Factors governing abundance of hydrolyzable amino acids in the sediments from Goban Spur transect. Prog Oceanogr 42:145-164

Bouloubassi I, Fillaux J, Saliot A (2001) Hydrocarbons in surface sediments from the Changjiang (Yangtze river) estuary, East China Sea. Mar Pollut Bull 42:1335-1346

Bourbonniere RA, Meyers PA (1996) Sedimentary geolipid records of historical changes in the watersheds and productivities of Lakes Ontario and Erie. Limnol Oceanogr 41:352-359

Brassell SC, McEvoy J, Hoffmann CF, Lamb NA, Peakman TM, Maxwell JR (1984) Isomerisation, rearrangement and aromatisation of steroids in distinguishing early stages of diagenesis. Org Geochem 6:11-23

Bray EE, Evans ED (1961) Distribution of $n$-paraffins as a clue to recognition of source beds. Geochim Cosmochim Acta 22:2-15

Byrne R, Ingram BL, Starratt S, Malamud-Roam F, Collins JN, Conrad ME (2001) Carbon-isotope, diatom, and pollen evidence for late Holocene salinity change in a brackish marsh in the San Francisco Estuary. Quat Res 55:66-76

Canuel EA, Freeman KH, Wakeham SG (1997) Isotopic compositions of lipid biomarker compounds in estuarine plants and surface sediments. Limnol Oceanogr 42:1570-1583

Chevalier N, Savoye N, Dubois S, Lama ML, David V, Lecroart P, le Ménach K, Budzinski H (2015) Precise indices based on $n$-alkane distribution for quantifying sources of sedimentary organic matter in coastal systems. Org Geochem 88:69-77

Chmura GL, Anisfeld SC, Cahoon DR, Lynch JC (2003) Global carbon sequestration in tidal, saline wetland soils. Glob Biogeochem Cycles $17: 1-22$

Cragg SM, Friess DA, Gillis LG, Trevathan-Tackett SM, Terrett OM, Watts JEM, Distel DL, Dupree P (2020) Vascular plants are globally significant contributors to marine carbon fluxes and sinks. Annu Rev Mar Sci 12:469-497

Cranwell PA (1984) Lipid geochemistry of sediments from Upton Broad, a small productive lake. Org Geochem 7:25-37

Cranwell PA, Eglinton G, Robinson N (1987) Lipids of aquatic organisms as potential contributors to lacustrine sediments-II. Org Geochem 11:513-527

Cunha AH, Santos R (2009) The use of fractals to assess seagrass landscape stability: a case study from the barrier island system of Ria Formosa (south of Portugal). Estuar Coast Shelf Sci 84:584-590 
Cunha AH, Assis J, Serrão EA (2009) Estimation of available seagrass meadow area in Portugal for transplanting purposes. J Coast Res 56: $1100-1104$

Dashtbozorg D, Bakhtiari AR, Shushizadeh MR, Taghavi L (2019) Quantitative evaluation of $n$-alkanes, PAHs, and petroleum biomarker accumulation in beach-stranded tar balls and coastal surface sediments in the Bushehr Province, Persian Gulf (Iran). Mar Pollut Bull 146:801-815

De la Rosa JM, González-Pérez JA, González-Vila FJ, Knicker H, Araújo MF (2011) Molecular composition of sedimentary humic acids from South West Iberian Peninsula: a multi-proxy approach. Org Geochem 42:791-802

De la Rosa JM, Araújo MF, González-Pérez JA, González-Vila FJ, Soares AM, Martins JM, Leorri E, Corbett R, Fatela F (2012) Organic matter sources for tidal marsh sediment over the past two millennia in the Minho River estuary (NW Iberian Peninsula). Org Geochem 53:16-24

Delgado J, Boski T, Nieto JM, Pereira L, Moura D, Gomes A, Sousa C, García-Tenorio R (2012) Sea-level rise and anthropogenic activities recorded in the late Pleistocene/Holocene sedimentary infill of the Guadiana Estuary (SW Iberia). Quat Sci Rev 33:121-141

Dignac MF, Houot S, Derenne S (2006) How the polarity of the separation column may influence the characterization of compost organic matter by pyrolysis-GC/MS. J Anal Appl Pyrolysis 75:128-139

Duarte P, Azevedo B, Guerreiro M, Ribeiro C, Bandeira R, Pereira A, Falcão M, Serpa D, Reia J (2008) Biogeochemical modelling of Ria Formosa (South Portugal). Hydrobiologia 611:115-132

Duarte CM, Losada IJ, Hendriks IE, Mazarrasa I, Marbà N (2013) The role of coastal plant communities for climate change mitigation and adaptation. Nat Clim Chang 3:96-968

Eganhouse RP, Pontolillo J (2008) Susceptibility of synthetic long-chain alkylbenzenes to degradation in reducing marine sediments. Environ Sci Technol 42:6361-6368

Eglinton G, Hamilton RJ (1967) Leaf epicuticular waxes. Science 156: $1322-1335$

Ficken KJ, Li B, Swain DL, Eglinton G (2000) An $n$-alkane proxy for the sedimentary input of submerged/floating freshwater aquatic macrophytes. Org Geochem 31:745-749

Filley TR, Cody GD, Goodell B, Jellison J, Noser C, Ostrofsky A (2002) Lignin demethylation and polysaccharide decomposition in spruce sapwood degraded by brown rot fungi. Org Geochem 33:111-124

Galletti GC, Reeves JB (1992) Pyrolysis/gas chromatography/ion-trap detection of polyphenols (vegetable tannins): preliminary results. Org Mass Spectrom 27:226-230

Gogou A, Stratigakis N, Kanakidou M, Stephanou EG (1996) Organic aerosols in Eastern Mediterranean: components source reconciliation by using molecular markers and atmospheric back trajectories. Org Geochem 25:79-96

González-Pérez JA, Almendros G, De la Rosa JM, González-Vila FJ (2014) Appraisal of polycyclic aromatic hydrocarbons (PAHs) in environmental matrices by analytical pyrolysis (Py-GC/MS). J Anal Appl Pyrolysis 109:1-8

Gonzalez-Vila FJ, Polvillo O, Boski T, Moura D, de Andrés JR (2003) Biomarker patterns in a time-resolved Holocene/terminal Pleistocene sedimentary sequence from the Guadiana river estuarine area (SW Portugal/Spain border). Org Geochem 34:1601-1613

Gough MA, Rowland SJ (1990) Characterization of unresolved complex mixtures of hydrocarbons in petroleum. Nature 344:648-650

Grantham PJ (1986) The occurrence of unusual C27 and C29 sterane predominances in two types of Oman crude oil. Org Geochem 9: $1-10$

Grimalt JO, Yruela I, Sáiz-Jiménez C, Toja J, De Leeuw JW, Albaiges J (1991) Sedimentary lipid biogeochemistry of a hypereutrophic alkaline lagoon. Geochim Cosmochim Acta 55:2555-2577
Grossi V, Raphel D (2003) Long-chain (C19-C29) 1-chloro- $n$-alkanes in leaf waxes of halophytes of the Chenopodiaceae. Phytochemistry 63:693-698

He D, Zhang K, Cui X, Tang J, Suna Y (2018) Spatiotemporal variability of hydrocarbons in surface sediments from an intensively humanimpacted Xiaoqing River-Laizhou Bay system in the eastern China: occurrence, compositional profile and source apportionment. Sci Total Environ 645:1172-1182

Hedges JI, Keil RG (1995) Sedimentary organic matter preservation: an assessment and speculative synthesis. Mar Chem 49:81-115

Hedges JI, Mann DC (1979) The characterization of plant tissues by their lignin oxidation products. Geochim Cosmochim Acta 43:18031807

Heim S, Schwarzbauer J, Kronimus A, Littke R, Woda C, Mangini A (2004) Geochronology of anthropogenic pollutants in riparian wetland sediments of the Lippe River (Germany). Org Geochem 35: 1409-1425

Hernandez ME, Mead R, Peralba MC, Jaffé R (2001) Origin and transport of $n$-alkane-2-ones in a subtropical estuary: potential biomarkers for seagrass-derived organic matter. Org Geochem 32:2132

Hines ME, Knollmeyer SL, Tugel JB (1989) Sulfate reduction and other sedimentary biogeochemistry in a northern New England salt marsh. Limnol Oceanogr 34:578-590

Huang WY, Meinschein WG (1979) Sterols as ecological indicators. Geochim Cosmochim Acta 43:739-745

Isobe KO, Zakaria MP, Chiem NH, Minh LY, Prudente M, Boonyatumanond R, Saha M, Sarkar S, Takada H (2004) Distribution of linear alkylbenzenes (LABs) in riverine and coastal environments in South and Southeast Asia. Water Res 38:24492459

Jaffé R, Mead R, Hernandez ME, Peralba MC, DiGuida OA (2001) Origin and transport of sedimentary organic matter in two subtropical estuaries: a comparative, biomarker-based study. Org Geochem 32:507-526

Jeng WL (2006) Higher plant $n$-alkane average chain length as an indicator of petrogenic hydrocarbon contamination in marine sediments. Mar Chem 102:242-251

Jiménez-Morillo NT, de la Rosa JM, Waggoner D, Almendros G, González-Vila FJ, González-Pérez JA (2016) Fire effects in the molecular structure of soil organic matter fractions under Quercus suber cover. Catena 145:266-273

Kaal J, Serrano O, Nierop KG, Schellekens J, Cortizas AM, Mateo MÁ (2016) Molecular composition of plant parts and sediment organic matter in a Mediterranean seagrass (Posidonia oceanica) mat. Aquat Bot 133:50-61

Kennicutt MC II, Barker C, Brooks JM, De Freitas DA, Zhu GH (1987) Selected organic matter source indicators in the Orinoco, Nile and Changjiang deltas. Org Geochem 11:41-51

Kim GB, Maruya KA, Lee RF, Lee JH, Koh CH, Tanabe S (1999) Distribution and sources of polycyclic aromatic hydrocarbons in sediments from Kyeonggi Bay, Korea. Mar Pollut Bull 38:7-15

Kumar M, Boski T, Lima-Filho FP, Bezerra FH, González-Vila FJ, González-Pérez JA (2018) Environmental changes recorded in the Holocene sedimentary infill of a tropical estuary. Quat Int 476:34 45

Kumar M, Boski T, Lima-Filho FP, Bezerra FH, González-Vila FJ, Alam Buhuiyan MK, González-Pérez JA (2019) Biomarkers as indicators of sedimentary organic matter sources and early diagenetic transformation of pentacyclic triterpenoids in a tropical mangrove ecosystem. Estuar Coast Shelf Sci 229:106403. https://doi.org/10.1016/j. ecss.2019.106403

Kumar M, Boski T, González-Vila FJ, Jiménez-Morillo NT, GonzálezPérez JA (2020) Characteristics of organic matter sources to the Guadiana estuary salt marsh sediments (SW Iberian Peninsula). 
Cont Shelf Res 197:104076. https://doi.org/10.1016/j.csr.2020. 104076

Leorri E, Mitra S, Irabien MJ, Zimmerman AR, Blake WH, Cearreta A (2014) A 700-year record of combustion-derived pollution in northern Spain: tools to identify the Holocene/Anthropocene transition in coastal environments. Sci Total Environ 470:240-247

Liste HH, Alexander M (2000) Accumulation of phenanthrene and pyrene in rhizosphere soil. Chemosphere 40:11-14

Mackenzie AS, Brassell SC, Eglinton G, Maxwell JR (1982) Chemical fossils: the geological fate of steroids. Science 217:491-504

Madureira MJ, Vale C, Gonçalves MS (1997) Effect of plants on sulphur geochemistry in the Tagus salt-marshes sediments. Mar Chem 58: 27-37

Martins M, Ferreira AM, Vale C (2008) The influence of Sarcocornia fruticosa on retention of PAHs in salt marsh sediments (Sado estuary, Portugal). Chemosphere 71:1599-1606

Mayer LM (1994) Surface area control of organic carbon accumulation in continental shelf sediments. Geochim Cosmochim Acta 58:12711284

McKirdy DM, Thorpe CS, Haynes DE, Grice K, Krull ES, Halverson GP, Webster LJ (2010) The biogeochemical evolution of the Coorong during the mid-to late Holocene: an elemental, isotopic and biomarker perspective. Org Geochem 41:96-110

Mcleod E, Chmura GL, Bouillon S, Salm R, Björk M, Duarte CM, Lovelock CE, Schlesinger WH, Silliman BR (2011) A blueprint for blue carbon: toward an improved understanding of the role of vegetated coastal habitats in sequestering $\mathrm{CO}_{2}$. Front Ecol Environ 9:552-560

Meyers PA (1997) Organic geochemical proxies of paleoceanographic, paleolimnologic, and paleoclimatic processes. Org Geochem 27: 213-250

Meyers PA, Eadie BJ (1993) Sources, degradation and recycling of organic matter associated with sinking particles in Lake Michigan. Org Geochem 20:47-56

Meyers PA, Ishiwatari R (1993) Lacustrine organic geochemistry-an overview of indicators of organic matter sources and diagenesis in lake sediments. Org Geochem 20:867-900

Meziane T, Bodineau L, Retiere C, Thoumelin G (1997) The use of lipid markers to define sources of organic matter in sediment and food web of the intertidal salt-marsh-flat ecosystem of Mont-SaintMichel Bay, France. J Sea Res 38:47-58

Miralles I, Piedra-Buena A, Almendros G, González-Vila FJ, Delgado Calvo-Flores R, González-Pérez JA (2015) Pyrolytic appraisal of the lignin signature in soil humic acids: assessment of its usefulness as carbon sequestration marker. J Anal Appl Pyrolysis 113:107-115

Mitsch WJ, Gosselink JG (1993) Wetlands, 2nd edn. Wiley, New York

Mizukawa K, Takada H, Ito M, Geok YB, Hosoda J, Yamashita R, Saha M, Suzuki S, Miguez C, Frias J, Antunes JC (2013) Monitoring of a wide range of organic micropollutants on the Portuguese coast using plastic resin pellets. Mar Pollut Bull 70:296-302

Mudge SM, Duce CE (2005) Identifying the source, transport path and sinks of sewage derived organic matter. Environ Pollut 136:209220

Mudge SM, East JA, Bebianno MJ, Barreira LA (1998) Fatty acids in the Ria Formosa lagoon, Portugal. Org Geochem 29:963-977

Mudge SM, Icely JD, Newton A (2008) Residence times in a hypersaline lagoon: using salinity as a tracer. Estuar Coast Shelf Sci 77:278-284

Newton A, Icely JD, Falcão M, Nobre A, Nunes JP, Ferreira JG, Vale C (2003) Evaluation of eutrophication in the Ria Formosa coastal lagoon, Portugal. Cont Shelf Res 23:1945-1961

Nierop KG, Speelman EN, de Leeuw JW, Reichart GJ (2011) The omnipresent water fern Azolla caroliniana does not contain lignin. Org Geochem 42:846-850

Odum WE, Fisher JS, Pickral JC (1979) Factors controlling the flux of particulate organic carbon from estuarine wetlands. In: Ecological processes in coastal and marine systems. Springer, US, pp 69-80
Ortiz JE, Díaz-Bautista A, Aldasoro JJ, Torres T, Gallego JLR, Moreno L, Estébanez B (2011) $n$-Alkan-2-ones in peat-forming plants from the Roñanzas ombrotrophic bog (Asturias, northern Spain). Org Geochem 42:586-592

Otto A, Simoneit BR (2001) Chemosystematics and diagenesis of terpenoids in fossil conifer species and sediment from the Eocene Zeitz formation, Saxony, Germany. Geochim Cosmochim Acta 65: 35053527

Ouyang X, Lee SY (2014) Updated estimates of carbon accumulation rates in coastal marsh sediments. Biogeosciences 11:5057-5071

Pacheco A, Vila-Concejo A, Ferreira Ó, Dias JA (2008) Assessment of tidal inlet evolution and stability using sediment budget computations and hydraulic parameter analysis. Mar Geol 247:104-127

Peters KE, Moldowan JM (1991) Effects of source, thermal maturity and biodegradation on the distribution and isomerization of homohopanes in petroleum. Org Geochem 17:47-61

Peters KE, Walters CC, Moldowan JM (2005) The biomarker guide. In: Biomarkers and isotopes in the environment and human history, vol 1, 2nd edn. Cambridge University press, NJ, p 471

Peulvé S, De Leeuw JW, Sicre MA, Baas M, Saliot A (1996a) Characterization of macromolecular organic matter in sediment traps from the northwestern Mediterranean Sea. Geochim Cosmochim Acta 60:1239-1259

Peulvé S, Sicre MA, Saliot A, De Leeuw JW, Baas M (1996b) Molecular characterization of suspended and sedimentary organic matter in an Arctic delta. Limnol Oceanogr 41:488-497

Qu WC, Dickman M, Wang SM, Wu RJ, Zhang PZ, Chen JF (1999) Evidence for an aquatic plant origin of ketones found in Taihu Lake sediments. Hydrobiologia 397:149-154

Quantin C, Joner EJ, Portal JM, Berthelin J (2005) PAH dissipation in a contaminated river sediment under oxic and anoxic conditions. Environ Pollut 134:315-322

Quemeneur M, Marty Y (1992) Sewage influence in a macrotidal estuary: fatty acid and sterol distributions. Estuar Coast Shelf Sci 34:347363

Ralph J, Hatfield RD (1991) Pyrolysis-GC-MS characterization of forage materials. J Agric Food Chem 39:1426-1437

Rampen SW, Abbas BA, Schouten S, Sinninghe Damste JS (2010) A comprehensive study of sterols in marine diatoms (Bacillariophyta): implications for their use as tracers for diatom productivity. Limnol Oceanogr 55:91-105

Ribeiro J, Monteiro CC, Monteiro P, Bentes L, Coelho R, Gonçalves JM, Lino PG, Erzini K (2008) Long-term changes in fish communities of the Ria Formosa coastal lagoon (southern Portugal) based on two studies made 20 years apart. Estuar Coast Shelf Sci 76:57-68

Rielley G, Collier RJ, Jones DM, Eglinton G (1991) The biogeochemistry of Ellesmere Lake, UK-I: source correlation of leaf wax inputs to the sedimentary lipid record. Org Geochem 17:901-912

Rommerskirchen F, Plader A, Eglinton G, Chikaraishi Y, Rullkötter J (2006) Chemotaxonomic significance of distribution and stable carbon isotopic composition of long-chain alkanes and alkan-1-ols in C4 grass waxes. Org Geochem 37:1303-1332

Sáiz-Jiménez C, De Leeuw JW (1984) Pyrolysis-gas chromatographymass spectrometry of isolated, synthetic and degraded lignins. Org Geochem 6:417-422

Schefuß E, Ratmeyer V, Stuut JBW, Jansen JF, Damsté JSS (2003) Carbon isotope analyses of $n$-alkanes in dust from the lower atmosphere over the central eastern Atlantic. Geochim Cosmochim Acta 67:1757-1767

Schwark L, Zink K, Lechterbeck J (2002) Reconstruction of postglacial to early Holocene vegetation history in terrestrial Central Europe via cuticular lipid biomarkers and pollen records from lake sediments. Geology 30:463-466

Sherblom PM, Gschwend PM, Eganhouse RP (1992) Aqueous solubilities, vapor pressures, and 1-octanol-water partition coefficients for C9-C14 linear alkylbenzenes. J Chem Eng Data 37:394-399 
Sicre MA, Peulvé S, Saliot A, De Leeuw JW, Baas M (1994) Molecular characterization of the organic fraction of suspended matter in the surface waters and bottom nepheloid layer of the Rhone delta using analytical pyrolysis. Org Geochem 21:11-26

Sousa C, Boski T, Pereira L (2019) Holocene evolution of a barrier island system, Ria Formosa, South Portugal. The Holocene 29:64-76

Stout SA, Magar VS, Uhler RM, Ickes J, Abbott J, Brenner R (2001) Characterization of naturally-occurring and anthropogenic PAHs in urban sediments-Wycoff/eagle harbor superfund site. Environ Forensic 2:287-300

Takada H, Ishiwatari R (1990) Biodegradation experiments of linear alkylbenzenes (LABs): isomeric composition of $\mathrm{C} 12 \mathrm{LABs}$ as an indicator of the degree of $\mathrm{LAB}$ degradation in the aquatic environment. Environ Sci Technol 24:86-91

Tanner BR, Uhle ME, Kelley JT, Mora CI (2007) C3/C4 variations in salt-marsh sediments: an application of compound specific isotopic analysis of lipid biomarkers to late Holocene paleoenvironmental research. Org Geochem 38:474-484

Tanner BR, Uhle ME, Mora CI, Kelley JT, Schuneman PJ, Lane CS, Allen ES (2010) Comparison of bulk and compound-specific $\delta^{13} \mathrm{C}$ analyses and determination of carbon sources to salt marsh sediments using $n$-alkane distributions (Maine, USA). Estuar Coast Shelf Sci 86:283-291

Terán A, González-Vila FJ, González-Pérez JA (2009) Detection of organic contamination in sediments by double-shoot pyrolysis-GC/ MS. Environ Chem Lett 7:301-308

Tinoco P, Almendros G, González-Vila FJ (2002) Impact of the vegetation on the lignin pyrolytic signature of soil humic acids from Mediterranean soils. J Anal Appl Pyrolysis 64:407-420

Tipple BJ, Pagani M (2013) Environmental control on eastern broadleaf forest species' leaf wax distributions and $\mathrm{D} / \mathrm{H}$ ratios. Geochim Cosmochim Acta 111:64-77

Van Heemst JD, Peulvé S, De Leeuw JW (1996) Novel algal polyphenolic biomacromolecules as significant contributors to resistant fractions of marine dissolved and particulate organic matter. Org Geochem 24:629-640

Venkatesan MI, Kaplan IR (1982) Distribution and transport of hydrocarbons in surface sediments of the Alaskan outer continental shelf. Geochim Cosmochim Acta 46:2135-2149

Volkman JK (1986) A review of sterol markers for marine and terrigenous organic matter. Org Geochem 9:83-99
Volkman JK, Farrington JW, Gagosian RB, Wakeham SG (1983) Lipid composition of coastal sediments from the Peru upwelling region. In: Bjoroy $\mathrm{M}$ et al (eds) Advances in organic geochemistry 1981. Wiley, Chichester, pp 28-240

Volkman JK, Holdsworth DG, Neill GP, Bavor HJ (1992) Identification of natural, anthropogenic and petroleum hydrocarbons in aquatic sediments. Sci Total Environ 112:203-219

Wakeham SG, Schaffner C, Giger W (1980) Polycyclic aromatic hydrocarbons in recent lake sediments-I. Compounds having anthropogenic origins. Geochim Cosmochim Acta 44:403-413

Wang Z, Liu Z, Yang Y, Li T, Liu M (2012) Distribution of PAHs in tissues of wetland plants and the surrounding sediments in the Chongming wetland, Shanghai, China. Chemosphere 89:221-227

Wen Z, Ruiyong W, Radke M, Qingyu W, Guoying S, Zhili L (2000) Retene in pyrolysates of algal and bacterial organic matter. Org Geochem 31:757-762

Yunker MB, Macdonald RW, Vingarzan R, Mitchell RH, Goyette D, Sylvestre S (2002) PAHs in the Fraser River basin: a critical appraisal of PAH ratios as indicators of PAH source and composition. Org Geochem 33:489-515

Zakaria MP, Okuda T, Takada H (2001) Polycyclic aromatic hydrocarbon (PAHs) and hopanes in stranded tar-balls on the coasts of Peninsular Malaysia: applications of biomarkers for identifying sources of oil pollution. Mar Pollut Bull 42:1357-1366

Zegouagh Y, Derenne S, Largeau C, Bertrand P, Sicre MA, Saliot A, Rousseau B (1999) Refractory organic matter in sediments from the North-West African upwelling system: abundance, chemical structure and origin. Org Geochem 30:101-117

Zhang J, Cai L, Yuan D, Chen M (2004) Distribution and sources of polynuclear aromatic hydrocarbons in Mangrove surficial sediments of Deep Bay, China. Mar Pollut Bull 49:479-486

Zielinska B, Sagebiel J, Arnott WP, Rogers CF, Kelly KE, Wagner DA, Lighty JS, Sarofim AF, Palmer G (2004) Phase and size distribution of polycyclic aromatic hydrocarbons in diesel and gasoline vehicle emissions. Environ Sci Technol 38:2557-2567

Publisher's note Springer Nature remains neutral with regard to jurisdictional claims in published maps and institutional affiliations. 